Journal of Thermal Engineering, Vol. 6, No. 2, Special Issue 11, pp. 65-91, March, 2020

Yildiz Technical University Press, Istanbul, Turkey

\title{
OPTIMIZATION OF A NEW CONFIGURATION OF POWER TRI-GENERATION CYCLE BY THE USE OF A MULTI-PURPOSE GENETIC ALGORITHM
}

\author{
Bardia Eftekhari ${ }^{1}$, M.A. Ehyaei ${ }^{1, *}$
}

\begin{abstract}
In the current study, a new configuration of power tri-generation cycle was suggested. In this cycle, the energy of hot gases output from the gas cycle in the heat recovery steam generator (HRSG), and the waste energy of the condenser in the steam cycle were recovered in the Organic Rankine Cycle (ORC). After the energy, exergy, and economic modeling of the cycle, the optimization of this cycle by the use of multipurpose genetic algorithm was performed. The objective functions were the electricity cost and the second law efficiency of thermodynamics. The variables chosen for optimization were the air to fuel molar ratio, the compression, and expansion ratio of the compressor and turbine of the gas cycle, the mass flow rate of water steam and refrigerant in steam cycles and ORC, the Pinch points between the gas cycle and steam, and steam cycles and ORC, and the maximum temperatures of the steam and ORC cycles. The optimization results showed that by choosing the optimal values of variables, the efficiency of the first and second thermodynamic laws, and the produced entropy would be $67.3 \%$, $68.9 \%$, and
\end{abstract}

$3342.5 \mathrm{~kW} / \mathrm{K}$. Also, the generated electricity cost was reduced to $0.049 \frac{\mathrm{US} \$}{\mathrm{kWh}}$.

Keywords: Tri-generation Cycle, Steam, ORC, Exergy, Genetic, Objective Function

\section{INTRODUCTION}

The renewable energy sources such as solar energy, geothermal energy, and a large amount of the heat waste in different industries, can be a potential source for meeting the demands of a part of world's energy consumption. The above mentioned thermal sources are known as the low-temperature thermal sources and cannot be transformed into electric energy by the conventional methods. Therefore, a great portion of these thermal sources is wasted. Recently, for transforming these low-temperature thermal sources into the electric power, several thermodynamic cycles such as Organic Rankine, Kalina, Supercritical Rankine, and Goswami have been proposed and investigated. The constraints on the non-renewable fossil energy sources on the one hand and the environmental concerns (greenhouse gases) on the other hand have led to serious challenges for the industrial management. During the recent years, the distribution of a great amount of energy from the heat waste such as the turbines and engines output gases, as well as the heat waste in different industries such as Steel, Cement and Ceramic Industries, in the environment, has led to serious environmental pollution and production of power from the low-temperature sources such as solar and ORC energy. The most common usages of small size cycles and ORC's are the geothermal power plants, biomass, and waste heat recovery functionalities. Among the advantages of this cycle is it's simplicity. Another important issue is the environmental aspect and its effects on the weather. As this cycle is a closed one, it does not produce any pollutants including the solid or liquid pollutants, or greenhouse gases. Although there are numerous claims about the $15-50 \%$ more output power of this cycle in similar thermal conditions, the data collected from the ORC and Kalina cycles in the real situation, and during their simulation in similar ambient temperatures and with the cooling system, suggest a significant difference of ORC [1].

One of the advantages of the use of ORC instead of Steam Rankine Cycle is that when the organic fluids are used for recovering the waste heat at temperatures lower than $573 \mathrm{~K}$, the thermal efficiency becomes economically justifiable. The ORC can be used for low-temperature waste heat recovery in some industries, for

This paper was recommended for publication in revised form by Regional Editor Omid Mahian

${ }^{1}$ Mechanical Engineering Department, Pardis Branch, Islamic Azad University, Pardis New City, Iran

${ }^{\star} E$-mail address: aliehyaei@yahoo.com

Orcid id: 0000-0003-3300-5417, 0000-0002-4721-9427

Manuscript Received 12 April 2018, Accepted 7 August 2018 
increasing the efficiency of power plants with production capacity of lower than 20MW, to generate energy from the geothermal and solar heat sources. Therefore, the use of ORC for recovering the waste heat energy is justifiable in many aspects. The better and more optimal use of energy and also, the decrease in emission intensity compared to the fossil power plants, leads to the lower effects of the output hot water on the life of the fishes and marine animals due to the working in lower temperatures, without increasing the discharge of the coolant water in the condenser [2]. Some of the examples of the heat with low waste (353-573K) are industrial waste flows, hot gases output from the heat exchanger and heater chimneys, the solar heat collected in the collectors, The smoke output from the diesel engines, biomass, and finally gas turbines. ORC has a lot of applications among which, the most extensive and best fields include waste heat recovery system, biomass power plant, geothermal power plants, and the solar heat energy[2].

There have been numerous studies conducted on ORC and its applications in heat recovery from the cycles and their optimization Schulitz, in 1986, has dealt with the thermodynamic analysis of the ORC cycle. The heat source of this ORC cycle is the output gases from the internal combustion engine. The temperature range of the output gases is between 473 to $773 \mathrm{~K}$. The results of this study show that about $60 \%$ of the internal combustion engine output gases could be recovered [3].Yamamoto et al., in 2001, investigated an ORC with HCFC-123 as the working fluid and concluded that this system is more efficient compared to the use of water as the working fluid [4].Wei et al. in 2007, provided an analysis and optimization of an ORC by the use of $(1,1,1,3,3$ Pentafluoropropane) that used HFC-245fa as the working fluid. Also, the thermodynamic functions of this ORC under the disorders were analyzed. The results showed that: the use of the output heat is a proper solution for improvement of the efficiency and net output power of the system; the degree of the condenser's output coolant should be low (0.5-0.6 K); when the ambient temperature is high, the net output power of the system is likely to be worsened with a 30\% deviation from the nominal value. Regarding the current environment, selection of an appropriate nominal value is a good solution for improvement of the efficiency and net output power of the system [5] .Mago et al. in 2007, dealt with the thermodynamic investigation of an ORC cycle for recovery of system waste energy. The fluids being investigated in this study were R134a, Propane, R112, R245a, R123, and Isobutane. They showed that R113 had the highest efficiency at 430K [6]. Invernizzi et al. in 2007, investigated the feasibility of a gas micro-turbine combined cycle and an ORC. The ORC cycle recovers the gas micro-turbine output gases at the temperature range of 523-573 K. Through the investigations on a gas micro-turbine with 100kWe size with an ORC cycle, the output power was increased by 1.3 times, and the efficiency of the mentioned cycle was also increased by $40 \%$, compared to the gas micro-turbine [7].Zhang and Li in 2007, investigated the thermal efficiency and unchangeably of an ORC to recover the waste heat. The results showed that Brazilian had the highest efficiency and the lowest unchanged ability in high-degree waste heat recovery [8].Roy et al., in 2010, dealt with the analysis of performance and parametric optimization of a heat recovery system by the use of R-12, R-123, and R-134a fluids, based on ORC technology. Three different fluids were chosen for this study and were compared to the Carnot productivity. The function parameters considered were the output work and the system efficiency. The results showed that R-123 had the highest output work and efficiency. The Carnot productivity for this fluid, in the modified pressure and under the similar conditions, was close to the real productivity. Therefore, selection of an ORC with R-123 fluid seems to be a desirable system to be used in the low-temperature heat sources for power production [9].Tchanche et al. in 2011, provided a review of ORC applications and analyzed them. These applications included the solar heat power generation, solar thermal -driven reverse osmosis desalination (Solar ORC-RO), Binary Rankine Cooling, Solar Power System Pellets, Oceanic Energy Conversion, Power Plants and Combined Biomass Heat, Binary Geothermal Systems and Recovery of Low-Heat Waste from Thermal Devices and Processes, and Rankin Cooling Systems parallel to absorbent systems in terms of the need for less stimulating components and more use of environment-friendly materials [2]. Ahmadi et al. in 2011, dealt with energy and environmental analysis of a combined ORC, gas micro-turbine, and absorption chiller system. The results indicated that the energy efficiency of this system is higher than that of CHP conventional systems. Also, the carbon dioxide production in this system is lower than the conventional systems [10].Wang et al. in 2012,investigated five different configurations of the ORC. These configurations are Rankine Cycle, Simple Organic with heat recovery, Simple Organic with open heat exchangers, Simple Organic with closed heat exchangers, and Simple Organic with reheat. 
They concluded that the best choice is the ORC with heat recovery [11].Pierobon et al. in 2013 found an optimal design of MW-sized ORC's by the use of multi-purpose optimization with the genetic algorithm. They considered three objective functions: thermal efficiency, the total system volume, and the Net Present Value. The optimization variables were the working fluid, the turbine inlet heat pressure, and the condensed heat of compression points of fluid velocity in heat exchangers. They used this method to recover the waste heat from the SGI-500 gas turbine installed on Draugen oil and gas platform, in the North Sea. The two optimal working fluids are Acetone and Cyclopentane, and the thermal efficiency and Net Present Value for cyclopentane were higher than Acetone [12].

Wang et al. in 2013, used the genetic algorithm as the optimization method, in a comparative study on an ORC with R-134a working fluid, for recovering the low-heat waste. Exergy efficiency and total investment cost were considered as two objective functions to be optimized under certain waste heat conditions. The Pareto limit obtained shows that the increase in exergy efficiency can lead to the increase in total investment costs of ORC [13].Tanczuk \& Ulbrich in 2013, dealt with the investigation of the combined gas-fueled internal combustion engine, gas boilers, and ORC system. The results showed that this system is economic in Germany. However, it is not economic in the Netherlands. The Payback Period for Germany and Netherlands were 9.2 and 15 years, respectively [14].Clemente et al. in 2013, dealt with the investigation of the combined thermodynamic cycle of the gas power plant with organic Rankine cycle. In the above analysis, the gas power plant had a gas turbine with heat recovery and nominal power of $100 \mathrm{~kW}$. The gas turbine outlet gases are recovered in an ORC. In this analysis, six working fluids and four types of ORC were studied [15].Darvish et al. in 2015,simulated the thermodynamic performance of a regenerative ORC which used a low-temperature heat source to help with the selection of proper organic working fluid. They use the thermodynamic models to investigate thermodynamic parameters such as ORC's output power and energy efficiency. Also, in this study, the electricity costs were estimated by the exergy-economic analysis. The working fluid was considered as a part of the investigation to determine the highest output power and energy efficiency in the system condition. The energy and rate of electricity cost were used as the objective functions for system optimization, and each fluid is evaluated based on optimal operational conditions. The high temperature and pressure rate are the independent variables of optimization [1].Carcasci and Winchler, in 2016, dealt with the investigation of an ORC for recovery of compressor outlet air heat. The two high- and low-pressure compressors were used in this analysis which was cooled between two compressing stages. The heat recovered from the air was used as the heat source of ORC thermal cycle. The results showed that through this method, the system efficiency is increased by about 10\% [16].Cao \& Dai, in 2017, investigated the efficiency of a combined cycle of gas turbine and ORC in different working conditions. Their results showed that ORC's with variable pressure have better performance compared to the ORC's with constant pressure [17].Khaljani et al. in 2015 investigated the exergy and economic analysis of the combined cycle of gas turbine and ORC cycle. In this research, steam produced in HRSG is transferred directly to the evaporator of ORC cycle, which is different from cycle configuration of this paper. In this paper, the heat exhausted from the condenser in steam cycle, can be recovered in ORC's evaporator [18].Carcasci et al.in 2014 also proposed a Thermodynamic analysis of an organic Rankine cycle for waste heat recovery from gas turbines their investigate showed cyclohexane is the best fluid for low oil temperature, benzene is the best choice for medium oil temperature and toluene should be used for high oil temperature. Configurations of cycle proposed are totally different from cycle configuration of this research [19].

Several papers have been investigated about the exergy, economic and environment analysis of gas turbine power plant, various methods of gas turbine cycle inlet air cooler, dispersed power generation systems have been published by the author of this paper [20-31]. A. Abbassi and M. Aliehyaei in 2004 investigated Exergy method of optimization of a wavy plate indirect evaporative cooler they understated although the exery analysis has high efficiency for thermal systems at a high temperature difference, nevertheless the present result show that this method may also be applied for systems with high fraction pressure loss and low temperature difference by this method can increase energy efficiency by up to 65\% [32].

E.Ghasemian and M. Aliehyaei in 2017worked on Evaluation and optimization of organic Rankine cycle (ORC) with algorithms NSGA-II, MOPSO, and MOEA for eight coolant fluids their result showed The selection of the optimization method depends on the desired objective of optimizing and the selected fluid. For optimization, the MOPSO method shows the best performance in terms of exergy and thermal efficiency; however, in terms of the 
costs, the three methods show different performance in different fluids [33]. Kazemi, and, Ehyaei, in 2018 investigated exergy, and economic analysis of a geothermal power plant, they coupled geothermal power planet cycle with ORC cycle in the next step exergy, and economic analysis were made, their results determined The highest and lowest amounts of the costs of exergy waste in the ORC with geothermal heat source were 78.1 and1.2 (US\$), for the turbine and pump [34].

Regarding the studies conducted so far, it can be found that no studies have been done on heat recovery from recovery boiler system condenser (HRSG). Also, there has been no newtri-generation system and its optimization through multi-purpose genetic algorithm proposed, so far. In the current study, the energy, exergy, and economic modeling of the gas turbine, recovery boiler, and ORC triple system. In fact, the proposed system is formed between the two stages of heat recovery. In the first stage, the heat energy of the gas turbine outlet gases is recovered, and the water is converted to high-pressure steam in the recovery boiler. In the second stage, the energy of steam turbine outlet low-pressure steam is transferred to the ORC working fluid and converts it to the super-heat steam. After the energy, exergy, and economic modeling of the mentioned system, based on the constrains on the system, the objective function is defined, and the tri-generation system is optimized through the use of the multi-purpose genetic algorithm. The innovations of the current study are as follows:

- Proposition of a new thermodynamic cycle for recovery of as much energy as possible

- Energy, exergy, and economic modeling of tri-generation system for the first time

- Definition of the constrains and objective function of the cycle for optimization

- $\quad$ Optimization of the cycle by the use of multi-purpose genetic algorithm

- Complete sensitivity analysis of calculated optimal values by the optimization algorithm

\section{MATHEMATICAL MODELING}

Figure 1 shows the gas, steam, and ORC triple cycle system.

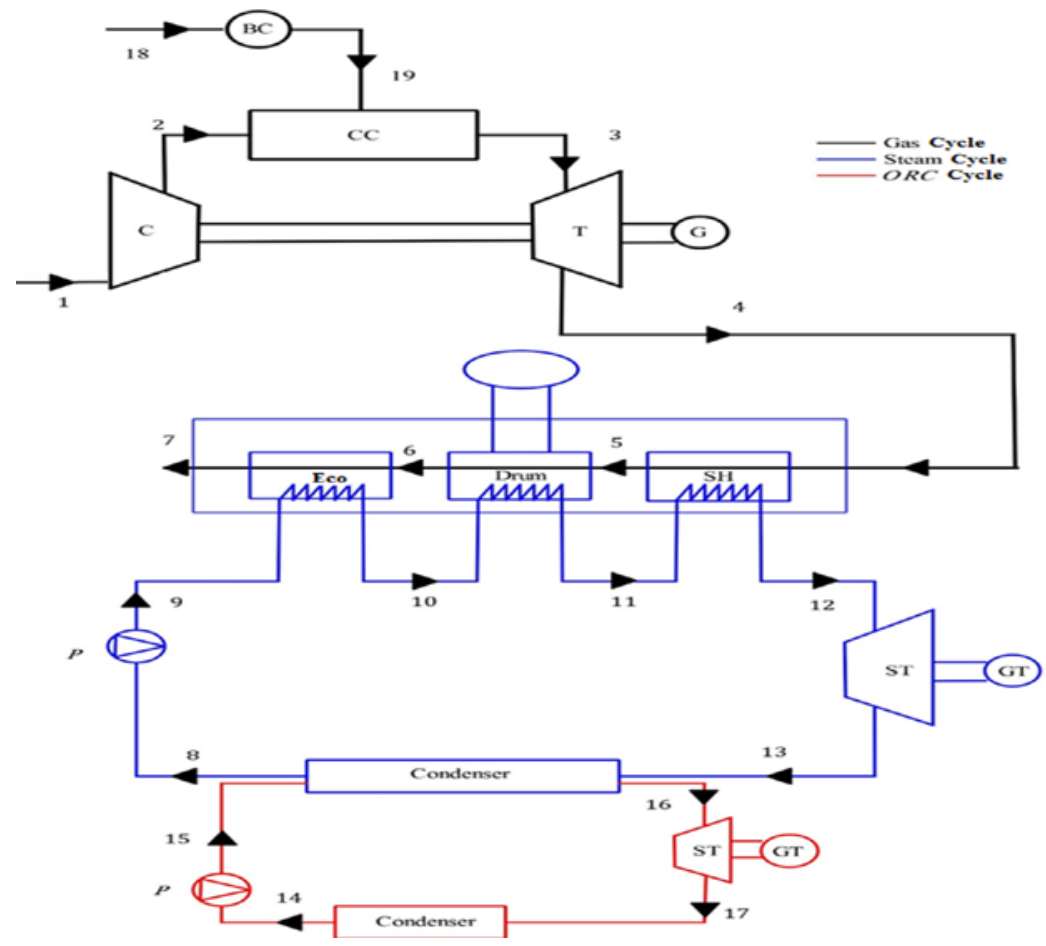

Figure 1. The gas, steam, and ORC triple cycle system 
In the system of figure 1, the air is entered at the point one in the environment condition, and it is condensed by the compressor (point 2). The condensed air at the pint 2, reacts with the fuel condensed in the compressor booster (point 19), in the combustion chamber (cc), and the fuel is combusted. The gases produced by the combustion are entered into gas turbine (point 3). This gas is expanded in the gas turbine and then generates power (point 4). This gas is entered into Heat recovery steam generation (HRSG) and converts the pump outlet water (point 9) into super-heat steam (point 12). The HRSG includes three parts namely the economizer, drum, and super heater. In the Economizer, the pump outlet condensed water converts into the saturated fluid (point 10). In the Drum, the saturated fluid converts into saturated steam (point 11). And in the super heater, the saturated steam converts into super-heat (point 12). The points 5, 6, and 7 show the gases outlet from super heater, Drum, and Economizer, respectively. The super-heat steam is expanded in the gas turbine and generates power (point 13). The steam expanded in the steam cycle condenser transfers its heat to the ORC operator (point 8). In the ORC, the condensed coolant working fluid (point 15) converts into the super-heat steam, after heat exchange with the steam cycle condenser (point 16). This superheated steam is expanded in the ORC's expander and generates power in this cycle (point 17). This expanded steam (point 17) exchanges heat with the ambient air, in the ORC's condenser, and coverts into the fluid (point 18).

In modeling the cycle of figure 1, the following assumptions have been considered:

1. The "steady state" conditions have been presumed.

2. The temperature and inlet air pressure have been presumed as $288 \mathrm{~K}$ and $101.3 \mathrm{kPa}$.

3. The air compressor pressure ratio and efficiency are presumed to be 10 and $85 \%$.

4. The temperature and pressure of natural gas input to the compressor booster are presumed to be $283 \mathrm{~K}$ and 250kPa.

5. The compressor booster pressure ratio and efficiency are presumed to be 5 and $80 \%$.

6. The molar ratio of fuel mixture components is accordance table (1).

7. The gas turbine pressure ratio and efficiency are presumed to be 11 and $80 \%$.

8. The air-to-fuel molar ratio in the gas turbine is 2.5 .

9. The pressure drop in the steam cycle and ORC is about 2 and $3 \%$.

10. The mass discharge of steam in the steam cycle is $78.9 \mathrm{~kg} / \mathrm{sec}$.

11. The pressure at the top and bottom of the steam cycle is 4000 , and $300 \mathrm{kPa}$, respectively.

12. The steam cycle pinch point $\left(T_{\mathrm{PP}, \mathrm{st}}\right)$ is presumed to be $313 \mathrm{~K}$.

13. The HRSG's efficiency is considered to be $95 \%$.

14. The pump and steam turbine efficiency are considered to be $85 \%$.

15. The mass discharge of the coolant in the ORC is $47.5 \mathrm{~kg} / \mathrm{s}$.

16. The pressure at the top and bottom of the ORC is 300 , and $70 \mathrm{kPa}$, respectively.

17. The ORC pinch point $\left(\mathrm{T}_{\mathrm{PP}, \mathrm{ORCt}}\right)$ is presumed to be $293 \mathrm{~K}$.

18. The pump and turbine efficiency in the ORC are considered to be $85 \%$.

The mass and energy balance equation are shown in Table 1. 
Journal of Thermal Engineering, Research Article, Vol. 6, No. 2, Special Issue 11, pp. 65-91, March, 2020

Table 1. The mass and energy balance of a system

\begin{tabular}{|c|c|c|c|}
\hline No. & Component & Mass rate balance & Energy rate balance \\
\hline \multicolumn{4}{|c|}{ Gas cycle } \\
\hline 1 & Compressor & $\dot{\mathrm{m}}_{1}=\dot{\mathrm{m}}_{2}$ & $W_{\text {comp }}=\frac{\dot{m}_{1}\left(h_{2}-h_{1}\right)}{\eta_{\text {comp }}}$ \\
\hline 2 & Booster compressor & $\stackrel{\mathrm{m}}{19}_{19}=\dot{\mathrm{m}}_{19}$ & $W_{\text {bcomp }}=\frac{\dot{m}_{9}\left(h_{19}-h_{18}\right)}{\eta_{\text {bcomp }}}$ \\
\hline 3 & Combustion chamber & $\dot{\mathrm{m}}_{2}+\dot{\mathrm{m}}_{19}=\dot{\mathrm{m}}_{\mathrm{a}}$ & $\dot{\mathrm{m}}_{2} \mathrm{~h}_{2}+\dot{\mathrm{m}}_{19} \mathrm{~h}_{19}=\dot{\mathrm{m}}_{\mathrm{a}} \mathrm{h}_{\mathrm{a}}$ \\
\hline 4 & Gas turbine & $\dot{\mathrm{m}}_{\mathrm{a}}=\dot{\mathrm{m}}_{4}$ & $W_{G T}=\dot{m}_{a}\left(h_{4}-h_{a}\right) \eta_{G T}$ \\
\hline \multicolumn{4}{|c|}{ Steam cycle } \\
\hline 5 & HRSG & $\dot{\mathrm{m}}_{9}=\dot{\mathrm{m}}_{10}=\tilde{\mathrm{m}}_{11}=\dot{\mathrm{m}}_{12}$ and $\tilde{\mathrm{m}}_{4}=\dot{\mathrm{m}}_{7}=\dot{\mathrm{m}}_{5}=\dot{\mathrm{m}}_{6}=\dot{\mathrm{m}}_{9}$ & $\dot{\mathrm{m}}_{4}\left(\mathrm{~h}_{4}-\mathrm{h}_{7}\right)-\dot{\mathrm{m}}_{12}\left(\mathrm{~h}_{12}-\mathrm{h}_{9}\right)$ \\
\hline 8 & Steam turbine & $\dot{\mathrm{m}}_{12}=\dot{\mathrm{m}}_{1 \mathrm{a}}$ & $W_{S T}=\dot{m}_{12}\left(h_{12}-h_{19}\right) \eta_{S T}$ \\
\hline 9 & Condenser & $\dot{\mathrm{m}}_{13}=\dot{\mathrm{m}}_{\mathrm{g}}$ & $\mathrm{Q}_{\mathrm{C}}=\dot{\mathrm{m}}_{\mathrm{g}}\left(\mathrm{h}_{1 \mathrm{a}}-\mathrm{h}_{\mathrm{g}}\right)$ \\
\hline 10 & Pump & $\dot{\mathrm{m}}_{\mathrm{g}}=\dot{\mathrm{m}}_{\mathrm{g}}$ & $\dot{\mathrm{w}}_{\mathrm{p}}=\frac{\dot{\mathrm{m}}_{\mathrm{B}}\left(\mathrm{h}_{\mathrm{g}}-\mathrm{h}_{\mathrm{B}}\right)}{\eta_{\mathrm{P}}}$ \\
\hline \multicolumn{4}{|c|}{ ORC } \\
\hline 11 & Pump & $\dot{m}_{14}=\dot{m}_{15}$ & $\mathrm{~W}_{\mathrm{p}}=\frac{\dot{\mathrm{m}}_{14}\left(\mathrm{~h}_{15}-\mathrm{h}_{14}\right)}{\eta_{\mathrm{p}}}$ \\
\hline 12 & Evaporator & $\dot{m}_{19}=\dot{m}_{g}$ and $\dot{m}_{15}=\dot{m}_{16}$ & $\mathrm{Q}_{\mathrm{E}}=\mathrm{m}_{15}\left(\mathrm{~h}_{16}-\mathrm{h}_{15}\right)$ \\
\hline 13 & ORC turbine & $\dot{\mathrm{m}}_{16}=\mathrm{m}_{17}$ & $\mathrm{~W}_{\mathrm{ORCT}}=\mathrm{m}_{16}\left(\mathrm{~h}_{17}-\mathrm{h}_{16}\right) \eta_{\mathrm{ORCT}}$ \\
\hline 14 & Condenser & $\dot{\mathrm{m}}_{17}=\dot{\mathrm{m}}_{14}$ & $\mathrm{Q}_{\mathrm{OC}}=\stackrel{\mathrm{m}}{\mathrm{m}}_{17}\left(\mathrm{~h}_{17}-\mathrm{h}_{14}\right)$ \\
\hline
\end{tabular}

For investigation and designing the combustion chamber, the gas analysis is needed, which is done based on Table $2[35,36]$. 
Journal of Thermal Engineering, Research Article, Vol. 6, No. 2, Special Issue 11, pp. 65-91, March, 2020

Table 2. Analysis of the gas consumed by gas turbine [37]

\begin{tabular}{|c|c|c|c|c|c|c|}
\hline i fraction & $\mathrm{CH}_{4}$ & $\mathrm{C}_{2} \mathrm{H}_{6}$ & $\mathrm{C}_{3} \mathrm{H}_{8}$ & $\mathrm{C}_{4} \mathrm{H}_{10}$ & $\mathrm{CO}_{2}$ & $\mathrm{~N}_{2}$ \\
\hline $\begin{array}{l}\mathrm{y}_{\mathrm{i}}, \% \text { Mole } \\
\text { fraction }\end{array}$ & 81 & 7.9 & 4.2 & 4.7 & 1.2 & 1 \\
\hline $\begin{array}{l}\mathrm{x}_{\mathrm{i}}, \% \text { Mass } \\
\text { fraction }\end{array}$ & 62.58 & 11.44 & 8.92 & 13.16 & 2.55 & 1.35 \\
\hline $\mathrm{M}_{\mathrm{i}}, \mathrm{kg} / \mathrm{kmole}$ & 16 & 30 & 44 & 58 & 44 & 28 \\
\hline $\mathrm{C}_{\mathrm{pi}}, \mathrm{kJ} / \mathrm{kg} \mathrm{K}$ & 2.25 & 1.76 & 1.67 & 1.64 & 0.84 & 1.04 \\
\hline & \multicolumn{2}{|c|}{$M_{f}=\sum y_{i} M_{i}=20.712(\mathrm{~kg} / \mathrm{kmoles})$} & \multicolumn{3}{|c|}{$\left(c_{p}\right)_{f}=\sum x_{i} c_{p_{i}}=2.013(\mathrm{~kJ} / \mathrm{kg} \mathrm{K})$} & \\
\hline \multicolumn{7}{|c|}{$R_{f}=\frac{R_{u}}{M_{f}}=0.401(\mathrm{~kJ} / \mathrm{kg} \mathrm{K})$} \\
\hline \multicolumn{7}{|c|}{$\left(C_{v}\right)_{f}=\left(C_{p}\right)_{f}-R_{f}=1.612(\mathrm{~kJ} / \mathrm{kg} \mathrm{K})$} \\
\hline \multicolumn{7}{|c|}{$k_{f}=\left(C_{p}\right)_{f} /\left(C_{v}\right)_{f}=1.249$} \\
\hline
\end{tabular}

For calculation of the temperature and combustion output, the below equation can be considered. The combustion process has been assumed to be the equilibrium:

$$
\begin{aligned}
& \left(0.81 \mathrm{CH}_{4}+0.079 \mathrm{C}_{2} \mathrm{H}_{6}+0.042 \mathrm{C}_{3} \mathrm{H}_{8}+0.047 \mathrm{C}_{4} \mathrm{H}_{10}+0.01 \mathrm{~N}_{2}+0.012 \mathrm{CO}_{2}\right)+2.412 r_{a}\left(\mathrm{O}_{2}+3.76 \mathrm{~N}_{2}\right) \rightarrow \\
& a^{\prime} \mathrm{CO}_{2}+b^{\prime} \mathrm{H}_{2} \mathrm{O}+e^{\prime} \mathrm{O}_{2}+g^{\prime} \mathrm{CO}+d^{\prime} \mathrm{N}_{2}+f^{\prime} \mathrm{NO}
\end{aligned}
$$

In which:

$r_{\mathrm{a}}$ is the air-to-fuel molar ratio, a', b', c', d', e', f', g' are the equation coefficients in the equation(7) which are calculated based on mass conservation.

Regarding the following equilibrium equations:

$$
\begin{gathered}
K_{\mathrm{CO}}=\frac{g^{2} e}{a^{2}}\left(\frac{P_{3}}{P_{2}}\right)^{2+1-2} 2 \mathrm{CO}_{2} \underset{\leftarrow}{\leftarrow} 2 \mathrm{CO}+\mathrm{O}_{2} \\
K_{\mathrm{NO}}=\frac{f^{2}}{d e}\left(\frac{P_{3}}{P_{2}}\right)^{2-1-1} \mathrm{~N}_{2}+\mathrm{O}_{2} \underset{\leftarrow}{\longrightarrow} 2 \mathrm{NO}
\end{gathered}
$$

In which, $K_{C O}$ is the equilibrium constant of the equation $2, K_{N O}$ is the equilibrium constant of the equation 3 , $P_{2}$ is the pressure before to entering the combustion chamber $(\mathrm{kPa}), P_{3}$ is the combustion pressure $(\mathrm{kPa})$, and a, b, c, d, e, f, g are the coefficients of equation 2 and 3. 
Journal of Thermal Engineering, Research Article, Vol. 6, No. 2, Special Issue 11, pp. 65-91, March, 2020

The combustion process in the combustion system is also considered as follows [38]:

$$
\sum \dot{m}_{p}\left(h_{f}^{\circ}+\left(h-h_{o}\right)\right)_{p}=\eta_{c c} \sum \dot{m}_{r}\left(h_{f}^{\circ}+\left(h-h_{o}\right)\right)_{r}
$$

In which, $\dot{m}_{P}$ is the mass flow of the products $(\mathrm{kg} / \mathrm{s})$, and $\dot{m}_{r}$ is the mass flow of the reactants $(\mathrm{kg} / \mathrm{s})$. $\eta_{c c}$ is the combustion efficiency, $\mathrm{h}$ is the enthalpy $(\mathrm{kJ} / \mathrm{kg}), h_{\circ}$ is the enthalpy at the reference temperature $(\mathrm{kJ} / \mathrm{kg})$, and $h_{f}^{\circ}$ is the enthalpy of formation $(\mathrm{kJ} / \mathrm{kg})$. Based on the equations 1 to 4 , and solving them, the combustion temperature and the products can be calculated.

the system first law efficiency is defined as:

$$
\eta_{I, g_{-} s t_{-} O R C}=\frac{\dot{W}_{n e t, g}+\dot{W}_{n e t, s t}+\dot{W}_{n e t, O R C}}{\dot{m}_{f} L H V}
$$

The exergy of the points 1 to 7, and 18 and 19 (gas turbine cycle) can be calculated from the following equation [38]:

$$
e x=e_{p h}+e_{c h}
$$

In the above equation, $e_{p h}$ and $e_{c h}$ are the physical and chemical exergy, respectively (kJ/kg).

The exergy of the steam cycle and ORC can be calculated from the following equation [35, 36].

$$
\mathrm{ex}=\sum \mathrm{x}_{\mathrm{i}} \mathrm{ex}_{\mathrm{chi}}+\frac{\mathrm{V}^{2}}{2}+\mathrm{gz}+\left(\mathrm{h}-\mathrm{h}_{0}\right)-\mathrm{T}_{0}\left(\mathrm{~s}-\mathrm{s}_{0}\right)+\mathrm{T}_{0} \sum \mathrm{x}_{\mathrm{i}} \mathrm{R}_{\mathrm{i}} \operatorname{lny}_{\mathrm{i}}
$$

The entropy production in the gas cycle and for the compressor, compressor's booster, combustion chamber, and the gas turbine are shown in table 3.

Table 3. The entropy production in the gas cycle

\begin{tabular}{|c|c|}
\hline Compressor & $\dot{S}_{g e n, c, g}=\frac{1}{T_{0}}\left[\dot{m}_{1} e x_{1}-\dot{m}_{2} e x_{2}-\dot{W}_{c, g}\right]$ \\
\hline Booster compressor & $\dot{S}_{g e n, b c, g}=\frac{1}{T_{0}}\left[\dot{m}_{18} e x_{18}-\dot{m}_{19} e x_{19}-\dot{W}_{b c, \mathrm{~g}}\right]$ \\
\hline Combustion Chamber & $\dot{S}_{g e n, \mathrm{cc}, g}=\frac{1}{T_{0}}\left[\dot{m}_{2} e x_{2}+\dot{m}_{19} e x_{19}-\dot{m}_{3} e x_{3}\right]$ \\
\hline Gas turbine & $\dot{S}_{g e n, t, g}=\frac{1}{T_{0}}\left[\dot{m}_{3} e x_{3}-\dot{m}_{4} e x_{4}-\dot{W}_{t, g}\right]$ \\
\hline
\end{tabular}


In the table $2 \dot{S}_{\text {gen }}$ is the entropy production $(\mathrm{kW} / \mathrm{K})$. The bc,g, cc,g, c,g, t,g subscripts represent compressor booster, combustion chamber, and gas compressor, gas turbine, respectively. The entropy production in the Economizer, Drum, Super Heater, Steam Turbine, and Condenser is shown in table 4.

Table 4. The entropy production in the steam cycle

\begin{tabular}{|c|c|}
\hline Pump & $\dot{S}_{g e n, P}=\frac{1}{T_{0}}\left[\dot{m}_{8} e x_{8}-\dot{m}_{9} e x_{9}-\dot{W}_{P}\right]$ \\
\hline Economizer & $\dot{S}_{g e n, \text { Есо }}=\frac{1}{T_{0}}\left[\dot{m}_{9} e x_{9}-\dot{m}_{10} e x_{10}+\dot{Q}_{E c o}\left(1-\frac{T_{0}}{T_{E c o}}\right)\right]$ \\
\hline Drum & $\dot{S}_{\text {gen }, \text { Drum }}=\frac{1}{T_{0}}\left[\dot{m}_{10} e x_{10}-\dot{m}_{11} e x_{11}+\dot{Q}_{\text {Drum }}\left(1-\frac{T_{0}}{T_{\text {Drum }}}\right.\right.$ \\
\hline Super heater & $\dot{S}_{g e n, S H}=\frac{1}{T_{0}}\left[\dot{m}_{11} e x_{11}-\dot{m}_{12} e x_{12}+\dot{Q}_{S H}\left(1-\frac{T_{0}}{T_{S H}}\right)\right]$ \\
\hline Steam turbine & $\dot{S}_{g e n, s t}=\frac{1}{T_{0}}\left[\dot{m}_{12} e x_{12}-\dot{m}_{13} e x_{13}-\dot{W}_{s t}\right]$ \\
\hline Condenser & $\dot{S}_{g e n, C o}=\frac{1}{T_{0}}\left[\dot{m}_{13} e x_{13}-\dot{m}_{8} e x_{8}+\dot{Q}_{C o}\left(1-\frac{T_{0}}{T_{C o}}\right)\right]$ \\
\hline
\end{tabular}

In the above table, ex to ex ${ }_{13}$ isthe exergy of the points given in figure $1(\mathrm{~kJ} / \mathrm{kg})$, and the $\mathrm{T}_{\mathrm{Eco}}, \mathrm{T}_{\mathrm{Drum}}, \mathrm{T}_{\mathrm{SH}}$ and $\mathrm{T}_{\mathrm{Co}}$ are the temperatures of the Economizer, Drum, Super Heater, and Condenser in the steam cycle (K), respectively. $\dot{Q}_{E c o}, \dot{Q}_{D r u m}, \dot{Q}_{S H}$, and $\dot{Q}_{C o}$ are the heat exchange rates of Economizer, Drum, Super Heater, and Condenser, respectively $(\mathrm{kW})$.

The entropy equations in ORC and for the pump, steam turbine, and condenser are similar to table 4. The efficiency of the second law of thermodynamics for the system can be calculated separately from the following equation:

$$
\eta_{I I, g-s t-O R C}=\frac{\dot{W}_{n e t, g}+\dot{W}_{n e t, s t}+\dot{W}_{n e t, O R C}}{\dot{m}_{18} e x_{18}}
$$

The objective equation for calculation of the cost of power generated by the gas turbine is defined as the following equation:

$$
\mathrm{C}_{\mathrm{E}}=\mathrm{C}_{1}+\mathrm{C}_{\mathrm{O}}+\mathrm{C}_{\mathrm{F}}
$$


In the above equation, $C_{E}$ is the power cost $(\$ / \mathrm{kWh}), C_{1}$ is the initial installation costs $(\$ / \mathrm{kWh}), C_{O}$ is the maintenance costs $(\$ / \mathrm{kWh})$, and $C_{F}$ is the fuel costs $(\$ / \mathrm{kWh})$.

The advantage of this method is the calculation of the costs based on each kilowatt of power production. Also, the cost of power can be calculated with the changes in parameters and conditions.

The electricity cost related to the initial installation can be calculated by the following equation:

$$
C_{I}=\frac{C I}{8760 \dot{W}_{n e t}}
$$

In which, $C$ is the initial installation costs (\$), and I is the profits from the initial costs.

The profits from the initial costs can be calculated as follows [39]:

$$
I=\frac{i(1+i)^{L}}{(1+i)^{L}-1}
$$

In the above equation, $L$ is the equipment life span (year), and $i$ is the interest rate. The maintenance costs were considered as $4 \%$ of the initial installation costs.

The fuel costs can be calculated from the following equation [39]:

$$
C_{F}=\frac{\text { Fuel } \cos t\left(\frac{\$}{k W h}\right)}{\eta_{I}}
$$

The fuel cost is equal to 0.0296 (US\$/kWh) [39].

Table 5 shows the equations for compressor, combustion chamber, and gas turbine equipment costs [40].

Table 5. The equations for compressor, combustion chamber, and gas turbine equipment costs

\begin{tabular}{|c|c|}
\hline Compressor & $C_{c, g}=\frac{c_{11} \dot{m}_{a}}{C_{12}-\eta_{c}}\left(\frac{P_{2}}{P_{1}}\right) \ln \left(\frac{P_{2}}{P_{1}}\right)$ \\
\hline Combustion Chamber & $C_{c c, g}=\frac{C_{21} \dot{m}_{a}}{C_{22}-\frac{P_{2}}{P_{3}}}\left(1+\exp \left(c_{23} \mathrm{~T}_{3}-c_{24}\right)\right)$ \\
\hline Gas turbine & $C_{t, g}=\left(\frac{C_{31} \dot{m}_{g}}{C_{32}-\eta_{\mathrm{t}, g}}\right) \ln \left(\frac{P_{3}}{P_{4}}\right)\left(1+\exp \left(c_{33} T_{3}-c_{34}\right)\right)$ \\
\hline
\end{tabular}

The $C_{11}, C_{12}, C_{22}, C_{21}, C_{23}, C_{24}, C_{31}, C_{32}, C_{33}, C_{34}$ equations are provided in the reference [40]. 
Table 6 shows the costs of the pump, HRSG, steam turbine, and condenser, in the steam cycle, the following equations can be used [41].

Table 6. The costs of the pump, HRSG, steam turbine, and condenser in the steam cycle

\begin{tabular}{|c|l|}
\hline Pump & $C_{p, s t}=3540\left(\dot{\mathrm{W}}_{\mathrm{p}}\right)^{0.71}$ \\
\hline HRSG & $C_{H R S G, s t}=4745\left(\frac{\dot{m}_{s t}\left(h_{12}-h_{9}\right)}{\log \left(T_{4}-T_{7}\right)}\right)^{0.8}+11820 \dot{m}_{s t}+658 \dot{m}_{g}$ \\
\hline Steam turbine & $C_{S t, s t}=6000\left(\dot{\mathrm{W}}_{n e t, s t}\right)^{0.7}$ \\
\hline Condenser & $C_{c o, s t}=1773 \dot{m}_{s t}$ \\
\hline
\end{tabular}

The purchase costs of the main equipment can be calculated by the equations provided in the references [42-44]The purchase costs of turbine, pump, condenser, operator, and generator of the ORC can be calculated by the equations shown in table 7 .

Table 7. The purchase costs of turbine, pump, condenser, operator, and generator of the ORC

\begin{tabular}{|c|c|}
\hline Steam turbine & $C_{S T, O R C}=2237\left(\dot{W}_{S T, O R C}\right)^{0.41}$ \\
\hline Pump & $C_{P, O R C}=16800\left(\frac{\dot{W}_{P, O R C}}{200}\right)^{0.67}$ \\
\hline Condenser & $C_{\text {Cond }, O R C}=43\left(\dot{Q}_{\text {Cond }, O R C}\right)^{0.68}$ \\
\hline HRVG & $C_{H R V G, O R C}=11.6779 \times \dot{Q}_{H R V G, O R C}+4416.105$ \\
\hline Generator & $C_{\text {Gen, ORC }}=2447\left(\dot{W}_{\text {Gen, ORC }}\right)^{0.49}$ \\
\hline
\end{tabular}

\section{GENETIC ALGORITHM}

The genetic algorithm is an optimization method inspired by the creatures' nature. This algorithm is based on iteration, and its principles are derived from the genetic science. In the genetic algorithm, the exploration methods act based on the selection mechanism and natural genetics. These algorithms select the most suitable threads from organized random information. In each generation, a new group of threads is formed by the best parts of the previous iterations, and a new random part is created for a suitable response. These threads efficiently explore the past information in the search space to advance to the new exploration point with better responses[45] .In general mode, when a genetic algorithm is applied, the following cycle is passed: 
Firstly, a primary population of people is selected randomly and without any specific criteria. For all the chromosomes (people) of the generation zero, the fitness value is determined based on the Fitness Function (objective function) which can be very simple, or complex. Then, through the different defined mechanisms for selection operator, a subset of the primary population will be selected. Afterwards, the crossover and mutations operations will be applied to the selected people, based on the problem statement. Now, these people on whom the genetic algorithm mechanisms were applied, should be compared to those of the primary population (generation zero), regarding to fitness value. (Definitely, we would expect the generation one's people have more fitness, regarding the application of the genetic algorithm operations on them. But it is not necessarily true). Anyways, there would remain some people with the highest fitness. These people, as a collection, will act as the primary population for the next stage.

The general design of an algorithm is as follows:

1) Initiation: create an n-chromosome population, randomly (the suitable solutions to the problem).

2) Fitness: evaluate the fitness $\mathrm{f}(\mathrm{x})$ of each chromosome $\mathrm{X}$ in the population.

3) Create a new population repeats the following stages until the new population is created:

i) Selection: select two chromosomes (parents) from the population, based on their fitness (the more the fitness, the more the chances of being selected).

ii) Crossover: based on the crossover probability, combine the parents for the creation of new offspring.

iii) Mutation: based on the mutation probability, mutate the offspring in each position in the locus.

iv) Acceptance: put the new offspring in the new population.

v) Replacement: use the newly created population in the algorithm process.

Figure 2 show the flow chart of Genetic Algorithm [46] .

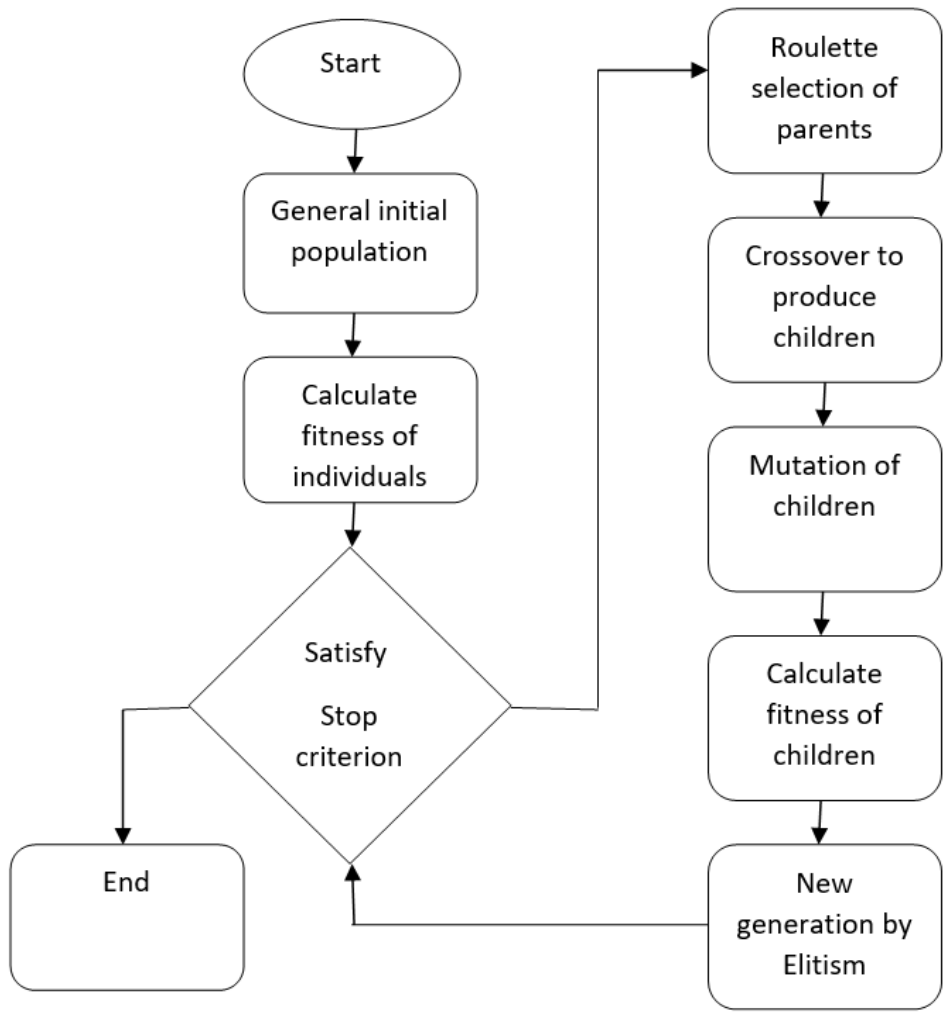

Figure 2. The flow chart of Genetic Algorithm[46] 


\section{RESULTS AND DISCUSSION}

For modeling the combinational cycle (GT+HRSG+ORC), an M-File has been written in MATLAB Software. The written M-Files Xsteam and Refprop were used for thermodynamic specifications of the steam and working fluids of the cycle [47] .For validation of the model, since the cycle proposed in the current study have not been presented in any other studies so far, the gas turbine cycle and the single-pressure HRSG are investigated. The specifications of the combined cycle presented in the reference [48] are input into the written code, and the results of the modeling are compared to the results of that reference. Regarding the evaluations, the highest error in the gas cycle first law efficiency is about $5.6 \%$, and in the steam cycle, it is $7.1 \%$.For system second law efficiency this difference is higher. For gas turbine is about $6.8 \%$ and for the steam cycle is about $8.6 \%$.

The specifications of the coolant fluid employed in this study are presented in Table 8 [47].

Table 8. Thermodynamic specifications of the ORC working fluid [47]

\begin{tabular}{|c|c|c|c|c|}
\hline No & Fluid & $T_{C}\left({ }^{0} C\right)$ & $P_{c}(k P a)$ & $M\left(\frac{k_{g}}{k m o l}\right)$ \\
\hline 1 & $\mathrm{R}_{11}$ & 198 & 440.8 & 137.4 \\
\hline
\end{tabular}

The multi-purpose algorithm genetic was used for optimization of the system. The variables defined for optimization and their change range are as follows:

$$
\begin{aligned}
& 1.7 \leq r_{a} \leq 2.7 \\
& 6 \leq r_{c} \leq 13 \\
& 6 \leq r_{t} \leq 13 \\
& 70\left(\frac{\mathrm{kg}}{\mathrm{s}}\right) \leq \dot{m}_{\text {Steam }} \leq 90\left(\frac{\mathrm{kg}}{\mathrm{s}}\right) \\
& 40\left(\frac{\mathrm{kg}}{\mathrm{s}}\right) \leq \dot{m}_{\text {ORC }} \leq 60\left(\frac{\mathrm{kg}}{\mathrm{s}}\right) \\
& 20\left({ }^{0} \mathrm{C}\right) \leq P P_{1} \leq 50\left({ }^{0} \mathrm{C}\right) \\
& 15\left({ }^{\circ} \mathrm{C}\right) \leq P P_{2} \leq 30\left({ }^{0} \mathrm{C}\right) \\
& \mathrm{T}_{12} \leq T_{\text {cr,Steam }}-20\left({ }^{0} \mathrm{C}\right) \\
& \mathrm{T}_{16} \leq T_{\text {cr,R11 }}-20\left({ }^{0} \mathrm{C}\right) \\
& \mathrm{T}_{13} \leq 1200\left({ }^{0} \mathrm{C}\right) \\
& R_{11}: \text { coolant }
\end{aligned}
$$

The objective functions are the cost of power generated by the cycle and the efficiency of the second law of thermodynamics $\left(C_{E}\left(\frac{U S \$}{k W h}\right)\right.$, and $\left.\eta_{I I, g-S t-O R C}\right)$.

The coolant fluid of the cycle is $\mathrm{R}_{11}$. 
In figure 3, the Pareto graph of the objective functions is shown. In this graph, the $\mathrm{x}$-axis is the cost of the generated power per $\left(\frac{U S \$}{k W h}\right)$, and the y-axis is the efficiency of the second law of thermodynamics. The trend of the shown graph is descending, i.e., by the decrease in the efficiency of the second law of thermodynamics, the cost of the power generated by the cycle is increased, and vice versa. The specifications of the dual-purpose genetic algorithm for the Pareto graph in figure 3 are shown in table 9. Table10shows the values of the variables, the efficiency of first and second laws of thermodynamics, the entropy production, and electricity cost before and after optimization.

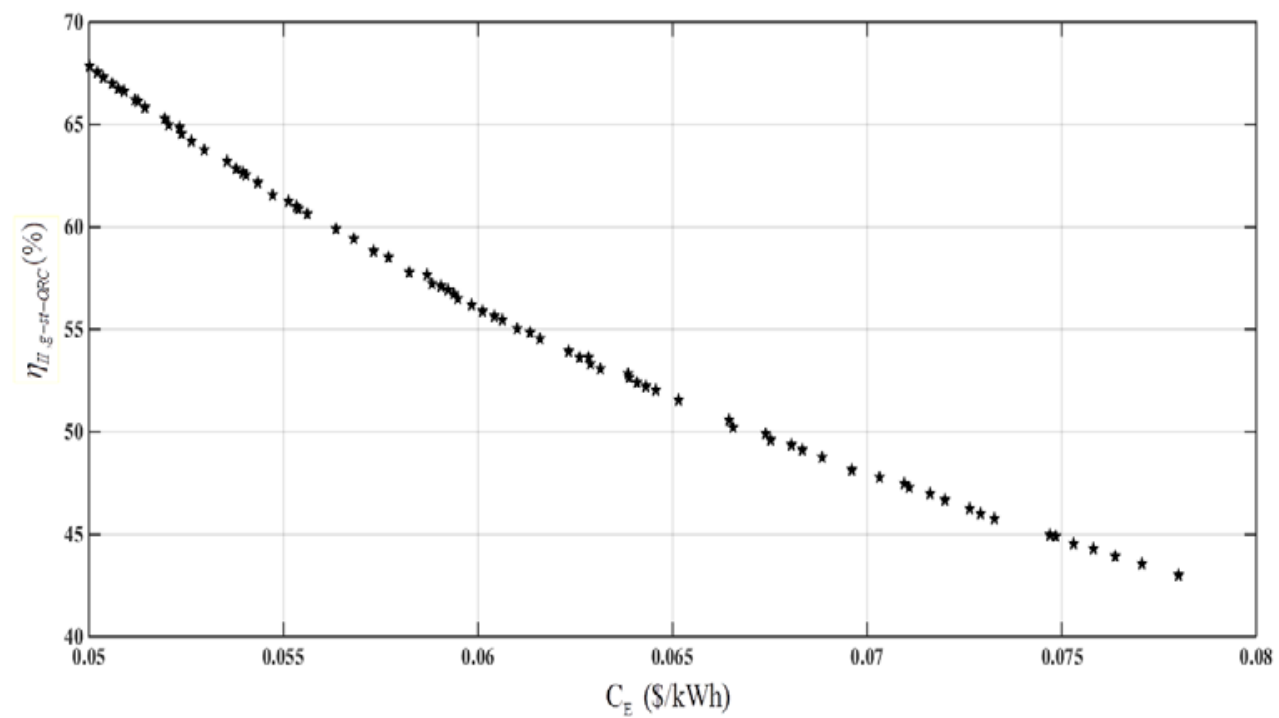

Figure 3. The Pareto graph of the cost of electricity generated by the triple cycle $C_{E}\left(\frac{U S \$}{k W h}\right)$ per efficiency of the second law of thermodynamics $\eta_{I I, g-s t-O R C}$

Table 9. The specifications of the multi-purpose genetic algorithm for optimization of tri-generation cycle

\begin{tabular}{|c|c|}
\hline Population Type & Double Vector \\
\hline Population Size & 200 \\
\hline Initial Population & 50 \\
\hline Initial Range & {$[-10 ; 10]$} \\
\hline Cross over fraction & 0.8 \\
\hline Generations & 700 \\
\hline Time limit & $\infty$ \\
\hline Function Tolerance & $10^{-4}$ \\
\hline Constraint Tolerance & $10^{-3}$ \\
\hline
\end{tabular}


Table 10. The values of the variables, the efficiency of first and second laws of thermodynamics, the entropy production, and electricity cost before and after optimization

\begin{tabular}{|c|c|c|}
\hline Variables & $\begin{array}{c}\text { Before } \\
\text { optimization }\end{array}$ & $\begin{array}{c}\text { After } \\
\text { optimization }\end{array}$ \\
\hline $\mathrm{r}_{\mathrm{a}}$ & 2.25 & 1.7 \\
\hline $\mathrm{r}_{\mathrm{c}}$ & 11.1 & 6.6 \\
\hline $\mathrm{r}_{\mathrm{t}}$ & 11.8 & 11.7 \\
\hline $\mathrm{PP}_{1}\left({ }^{0} \mathrm{C}\right)$ & 40 & 23.1 \\
\hline$\dot{m}_{\text {Steam }}\left(\frac{\mathrm{kg}}{\mathrm{s}}\right)$ & 78.9 & 89.9 \\
\hline$\dot{m}_{\text {ORC }}\left(\frac{\mathrm{kg}}{\mathrm{s}}\right)$ & 47.5 & 55.8 \\
\hline $\mathrm{PP}_{2}\left({ }^{0} \mathrm{C}\right)$ & 20 & 19.4 \\
\hline$\eta_{I}(\%)$ & 52.1 & 67.3 \\
\hline$\eta_{I I}(\%)$ & 53.4 & 68.9 \\
\hline$\dot{S g}_{g e n}\left(\frac{\mathrm{kW}}{\mathrm{K}}\right)$ & 3062.6 & 3342.5 \\
\hline$C_{E}\left(\frac{\$}{k W h}\right)$ & 0.0632 & 0.049 \\
\hline
\end{tabular}

Based on the values in table 10, it can be concluded that optimization of the cycle has led to the increase in efficiency of the first and second laws of thermodynamics from $52.1 \%$ and $53.4 \%$, to $67.3 \%$ and $68.9 \%$. However, this increase in the efficiency has led to the rise in entropy production from $3062.2(\mathrm{~kW} / \mathrm{K})$ to $3342.5(\mathrm{~kW} / \mathrm{K})$. From another aspect, in general, the cost of the electricity generated by the tri-generation cycle has been reduced from 0.0632 $\left(\frac{U S \$}{k W h}\right)$ to $0.049\left(\frac{U S \$}{k W h}\right)$. Figure 4 shows the optimal value of the efficiency of the second law of the thermodynamics in the cycle per different populations of genetic algorithms. It is obvious in the figure that from the pairs above 200, the optimal response is constant. Therefore, the evaluation of the optimal responses of the population was also done. in order not to affect the optimal response.

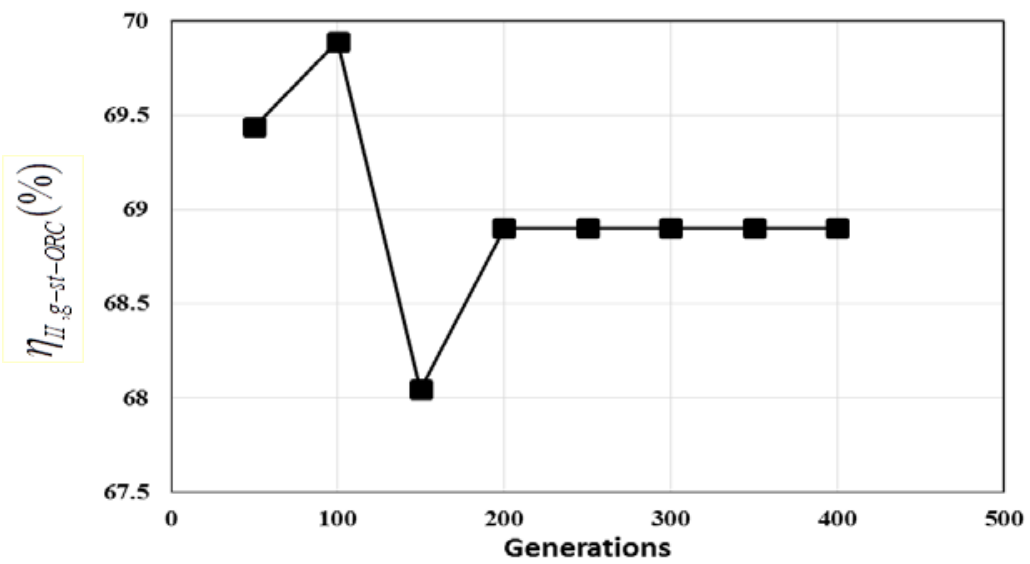

Figure 4. The optimal value of the second law of thermodynamics efficiency in power generation cycle per different populations of genetic algorithm 
Figure 5 shows the changes in the efficiency of the second law of thermodynamics in tri-generation cycle per air-to-fuel molar ratio $\left(\mathrm{r}_{\mathrm{a}}\right)$ and different pressure ratios of the compressor. From the changes in the figure, it can be concluded that by the increase in pressure ratio of the compressor to the air-to-fuel molar ratio, the efficiency of the second law of thermodynamics in the tri-generation cycle is decreased. By the increase in the air-to-fuel molar ratio, considering that the gas turbine outlet temperature is decreased, the efficiency of the steam cycles and ORC is also reduced, which lead to the subsequent decrease in overall efficiency of the cycle. From another point of view, by the increase in the air compressor pressure ratio, two opposite effects can be observed: 1) increase in the compressor consumed power, and 2) increase in the compressor outlet temperature as a result of which, the combustion occurs in a higher temperature. This increase in combustion temperature would subsequently increase the efficiency of the steam cycles and ORC. Based on the changes in the graph, it is clear that the first effect dominates the second one. Figure 6 shows the changes in the efficiency of the first law of thermodynamics for the tri-generation cycle per air-to-fuel molar ratio $\left(\mathrm{r}_{\mathrm{a}}\right)$, and in different pressure ratios of the air compressor. The process changes of figure 6 are similar to figure 5.

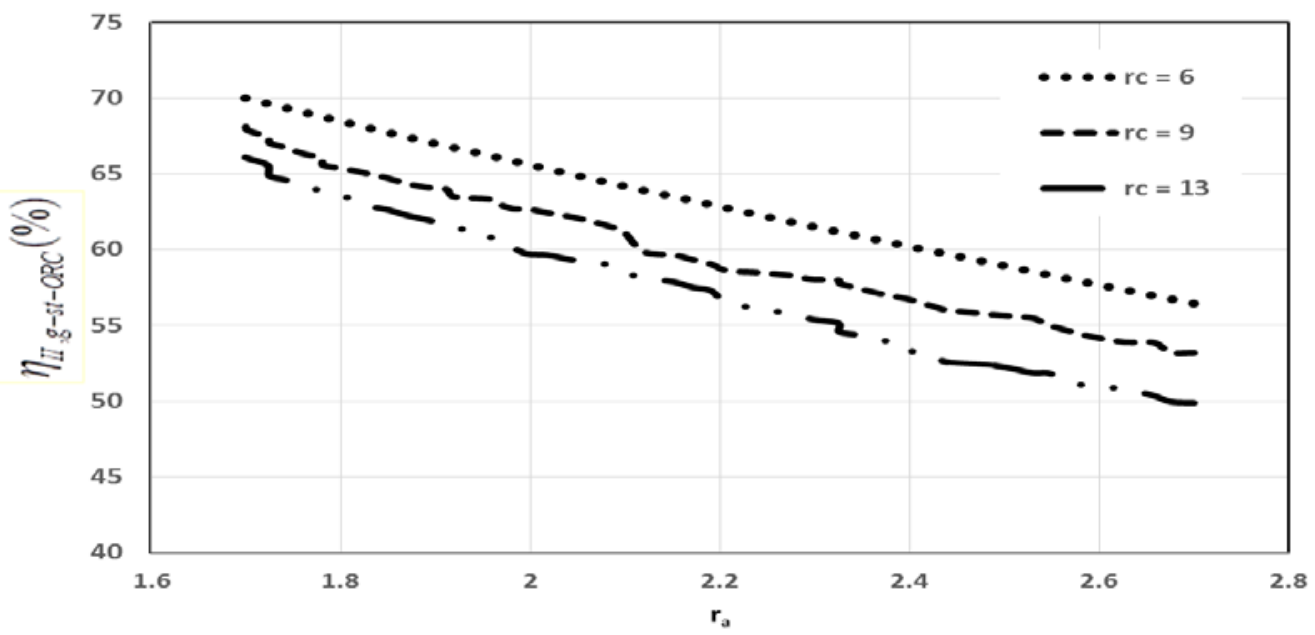

Figure 5. The changes in efficiency of second law of thermodynamics for the tri-generation cycle per air-to-fuel molar ratio $\left(\mathrm{r}_{\mathrm{a}}\right)$, and in different pressure ratios of the air compressor $\left(\mathrm{r}_{\mathrm{c}}\right)$

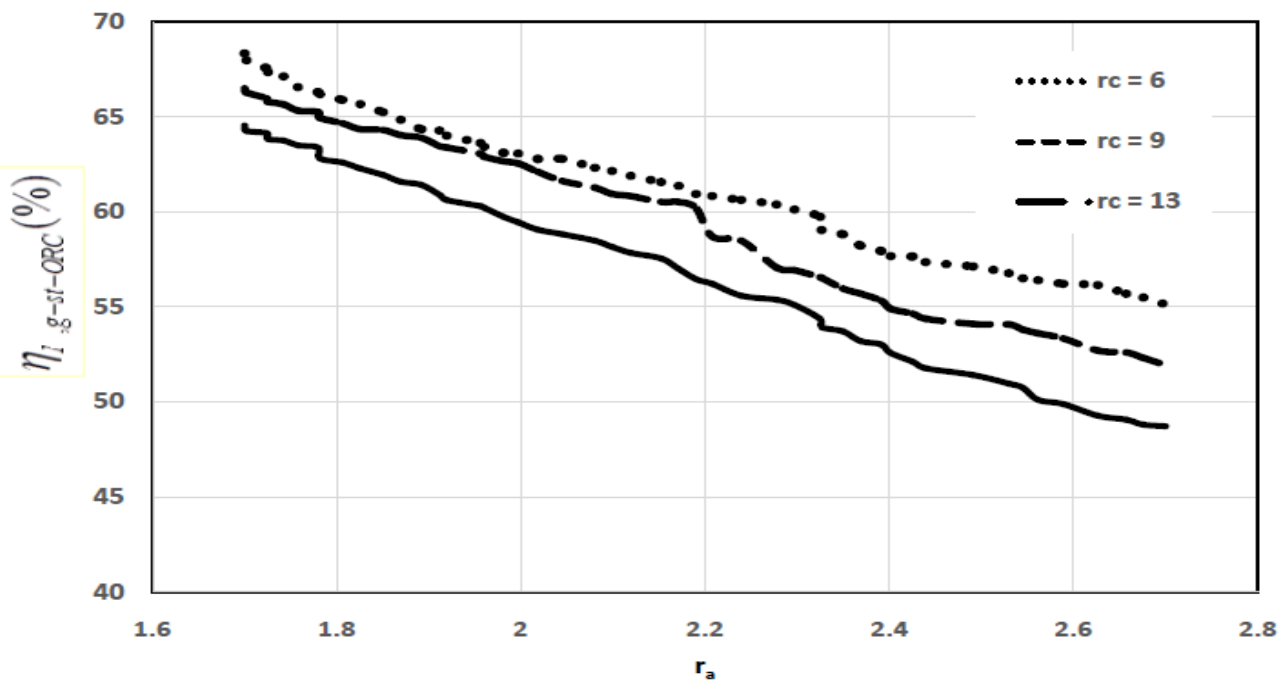

Figure 6. The changes in efficiency of first law of thermodynamics for the tri-generation cycle per air-to-fuel molar ratio $\left(r_{a}\right)$, and in different pressure ratios of the air compressor $\left(r_{c}\right)$ 
It should be noted that in the figures 5 and 6 , all the values except the air-to-fuel molar ratio $\left(r_{a}\right)$ and compressor pressure ratio $\left(r_{c}\right)$, have been chosen as optimal. Figure 7 shows the efficiency of the second law of thermodynamics for a gas cycle, gas cycle with steam and gas, steam, and ORC triple cycle, per air-to-fuel ratio. It indicates that by the increase in the air-to-fuel molar ratio, the efficiency of the second law of thermodynamics is reduced for all the three cycles; the efficiency range of the gas cycle is from 26 to $23 \%$, for the gas and steam combined cycle, it is from 65 to $52 \%$, and for the tri-generation cycle, it is from 70 to $56 \%$. It should be noted that in figure 7, all the optimal values of the changes which have been calculated by the dual-purpose genetic algorithm, are entered into the software as input.

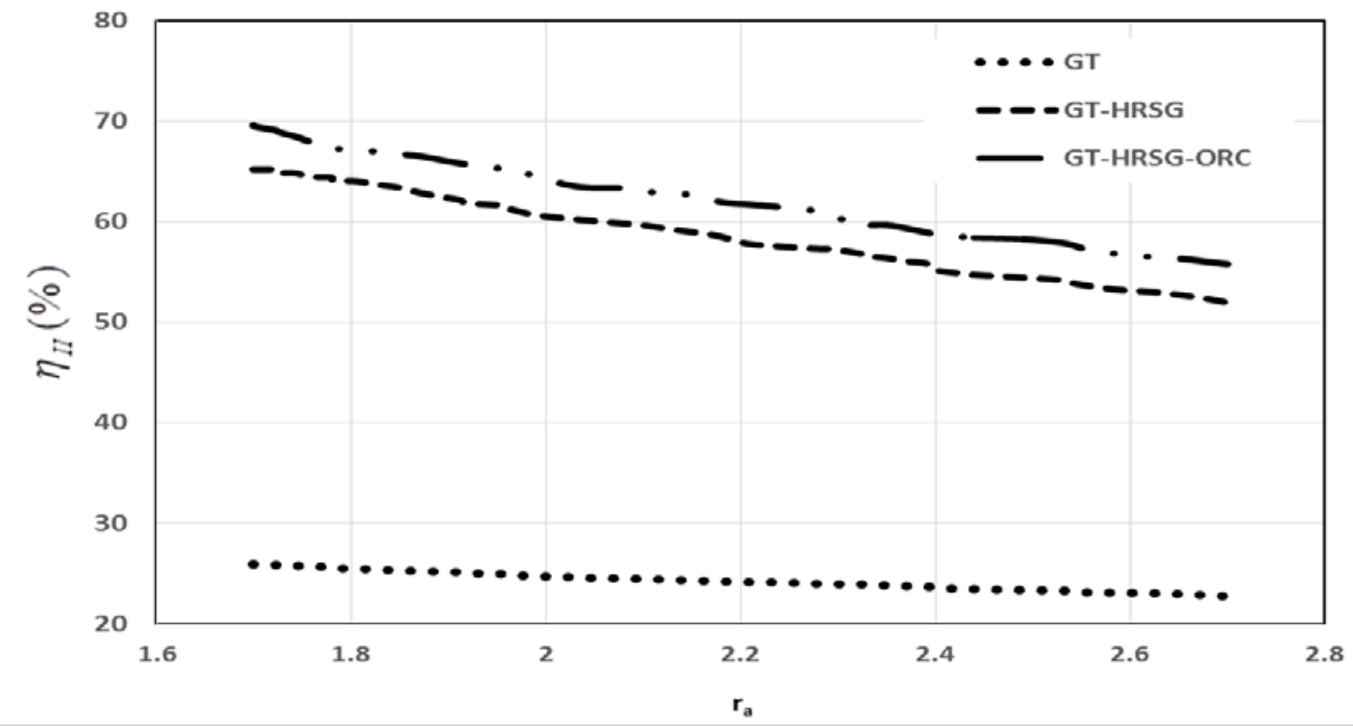

Figure 7. The changes in efficiency of the second law of thermodynamics for gas cycle, dual cycle, and trigeneration cycle per air-to-fuel molar ratio $\left(\mathrm{r}_{\mathrm{a}}\right)$

Figure 8 shows the changes in the efficiency of the second law of thermodynamics for tri-generation cycle per gas turbine expansion ratio. In this figure, all the optimal values obtained from the dual-purpose genetic algorithm, except the gas turbine expansion ratio $\left(\mathrm{r}_{\mathrm{t}}\right)$, have been selected. The trend of the graph changes shows that change in gas turbine expansion ratio from 6 to 13, would lead to the increase in efficiency of the second law of thermodynamics from 68.5 to $69 \%$. It can be concluded that the changes in gas turbine expansion coefficient have no significant effects on the efficiency of the second law of thermodynamics in tri-generation cycle.

In general, the increase in gas turbine expansion ratio has the following effects:

1) Increase in the gas turbine output power due to the rise in the gas turbine expansion ratio

2) Decrease in the gas turbine outlet temperature that is subsequently effective on the steam output from HRSG.

From the graph change trend, it can be concluded that the first effect dominates the second one. However, in general, the change in the gas turbine expansion coefficient has no significant effects on the efficiency of the second law of thermodynamics in the tri-generation cycle. 


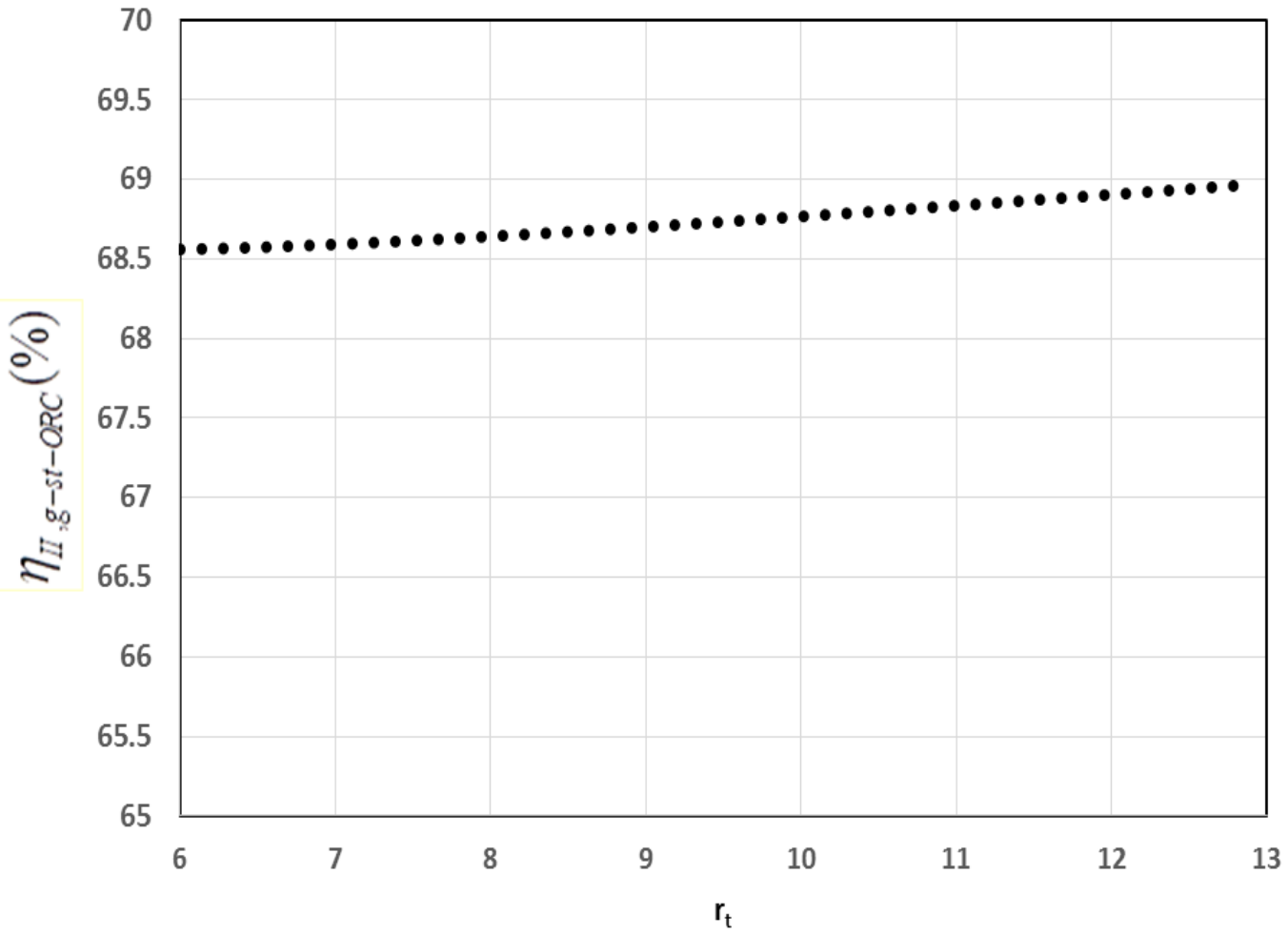

Figure 8. The changes in efficiency of the second law of thermodynamics in the tri-generation cycle per gas turbine expansion ratio

Figure 9 shows the changes in the efficiency of the second law of the thermodynamics in tri-generation cycle per Pinch Point $\left(\mathrm{PP}_{1}\right)$ between the combustion output gases of gas turbine and HRSG's steam at the point 12 in figure 1 . According to the graph, by the increase in $\mathrm{PP}_{1}$, the efficiency of the second law of thermodynamics in the tri-generation cycle is decreased. The reason behind this phenomenon is the increase in the wastages and irreversibility due to the increase in temperature difference between the hot gas and HRSG steam.

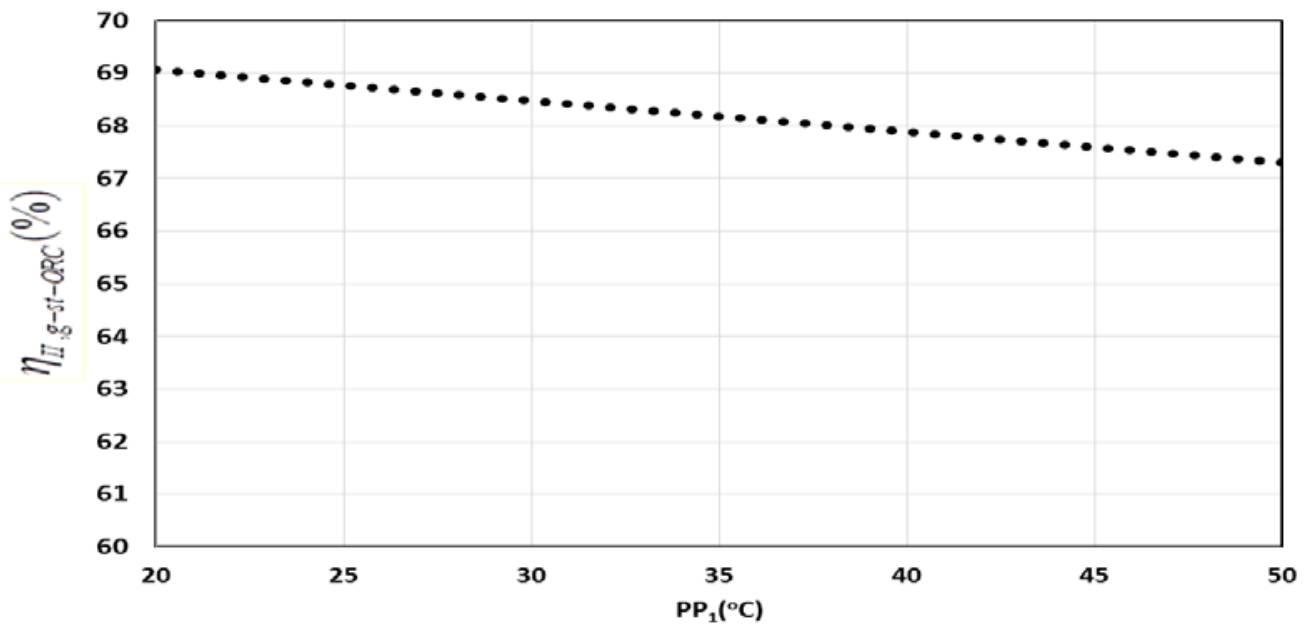

Figure 9. The changes in the efficiency of the second law of the thermodynamics in tri-generation cycle per Pinch Point $\left(\mathrm{PP}_{1}\right)$ 
Figure 10 shows the changes in the cost of electricity generated by the tri-generation cycle per air-to-fuel ratio, and in different density ratios of the gas cycle air compressor. In this figure, the residuals of the variable have been considered to be the optimal values of table 10. Figure 10 shows that by the increase in air-to-fuel molar ratio, as well as the compressor's pressure ratio, the cost of the electricity generated by the tri-generation cycle would increase.

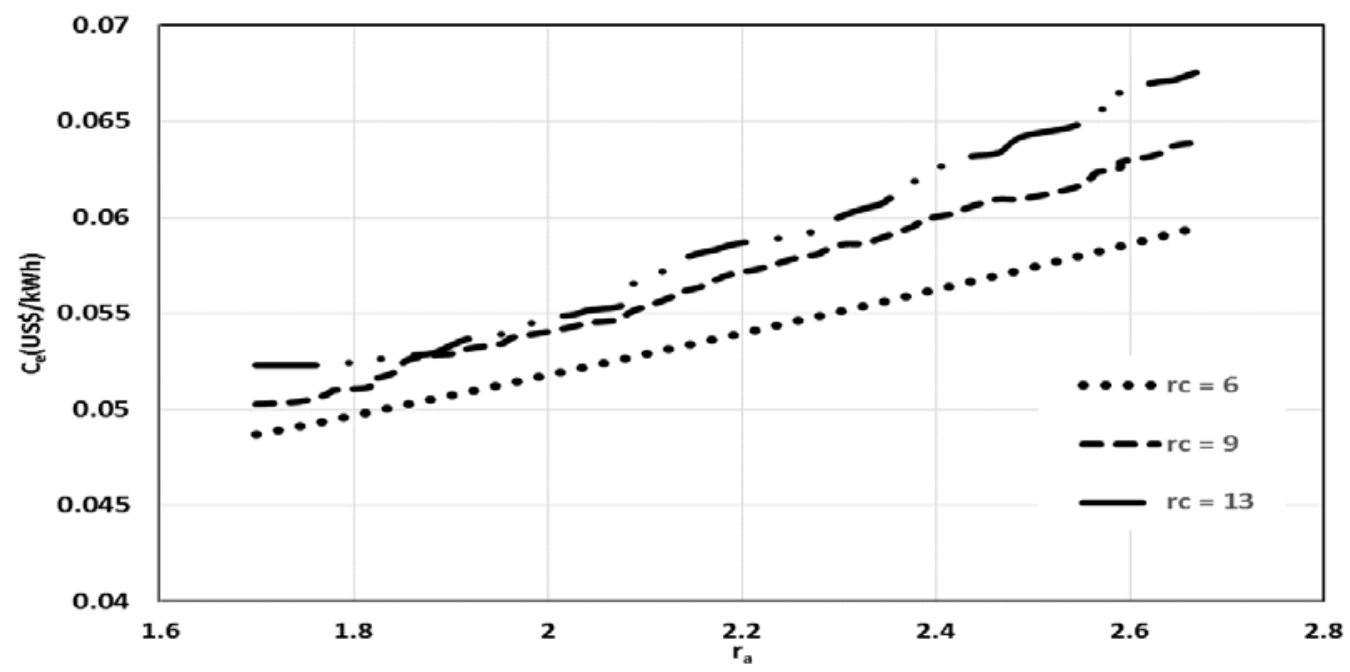

Figure 10. The cost of electricity generated by the tri-generation cycle per air-to-fuel ratio( $\left.\mathrm{r}_{\mathrm{a}}\right)$

Figure 11 shows the changes in the initial equipment costs $\left(\mathrm{C}_{\mathrm{I}}\right)$ per air-to-fuel molar ratio. In this figure, all the values except the air-to-fuel molar ratio, have been assumed to be optimal values in the table10. In fact, in this figure, the share of the initial equipment costs $\left(\mathrm{C}_{\mathrm{I}}\right)$ in the electricity costs and its changes based on the air-to-fuel molar ratio has been investigated. By the increase in the air-to-fuel molar ratio, though the tri-generation cycle output power is increased, the equipment purchase costs are also increased. As a result, the cost of electricity related to the initial equipment costs is increased by the rise in the air-to-duel molar ratio.

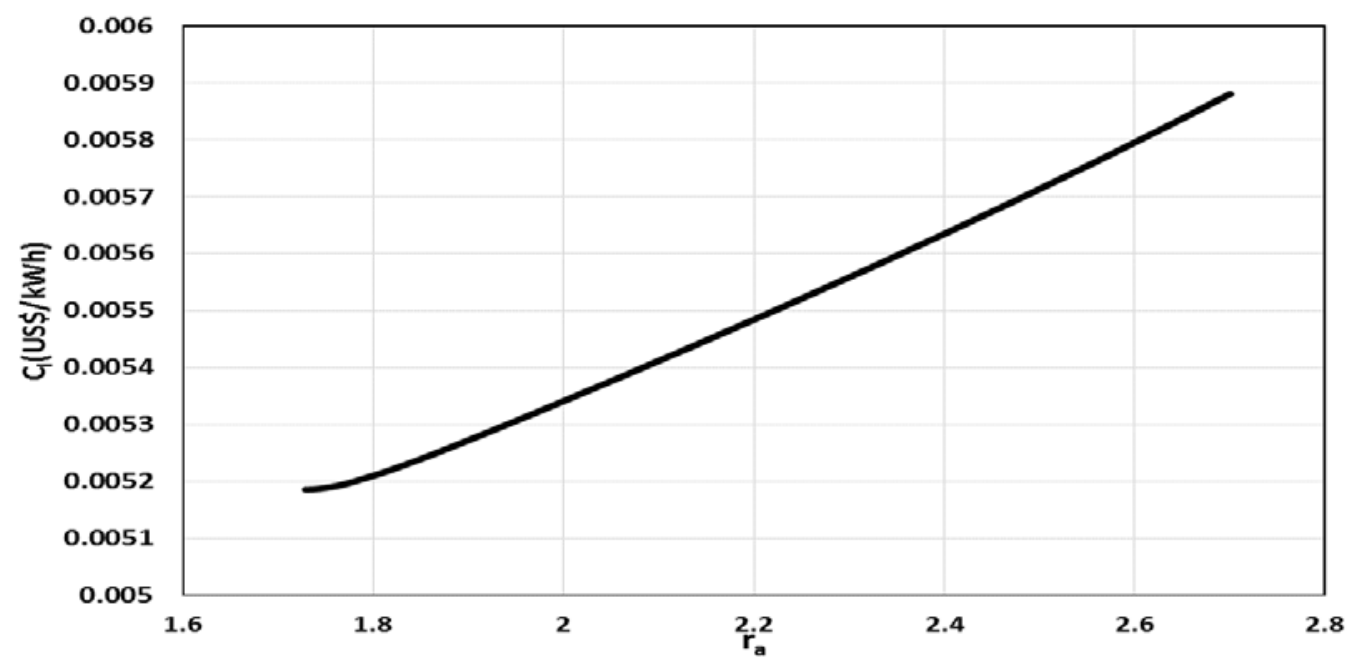

Figure 11. The changes in the cost of electricity in the initial equipment costs $\left(\mathrm{C}_{\mathrm{I}}\right)$ per air-to-fuel molar ratio

Figure 12 shows the changes in the cost of electricity generated by the tri-generation cycle per Pinch Point $\left(\mathrm{PP}_{1}\right)$ between the gas cycle output and HRSG's steam. It can be understood from the figure that by the increase in $\left(\mathrm{PP}_{1}\right)$, the electricity cost is increased. In fact, by the increase in $\left(\mathrm{PP}_{1}\right)$, two effects can be observed: 1$)$ the decrease 
in the cycle efficiency that leads to the increase in electricity cost, 2) increasing the heat exchange level between the gas fluid and steam in the HRSG exchanger that leads to the increase in initial equipment costs and subsequent rise in the electricity cost. Regarding the above mentioned two effects, by the increase in $\left(\mathrm{PP}_{1}\right)$, the rise in the electricity cost seems logical. Figure 13 shows the changes in costs of electricity generated by the cycle in three modes as gas turbine cycle, dual gas and steam cycle, and tri-generation cycle of gas, steam, and ORC. The overall trend of the figure shows that converting the cycle from the gas mode to the dual gas and steam mode would lead to the decrease in the electricity cost by about $50 \%$.

Therefore, it can be concluded that the initial equipment costs of the steam cycle are ignorable, considering the rise in efficiency and the reduction in fuel consumption. However, for the tri-generation cycle (GT+HRSG+ORC), this decrease in the electricity costs is about $5 \%$, which is negligible.

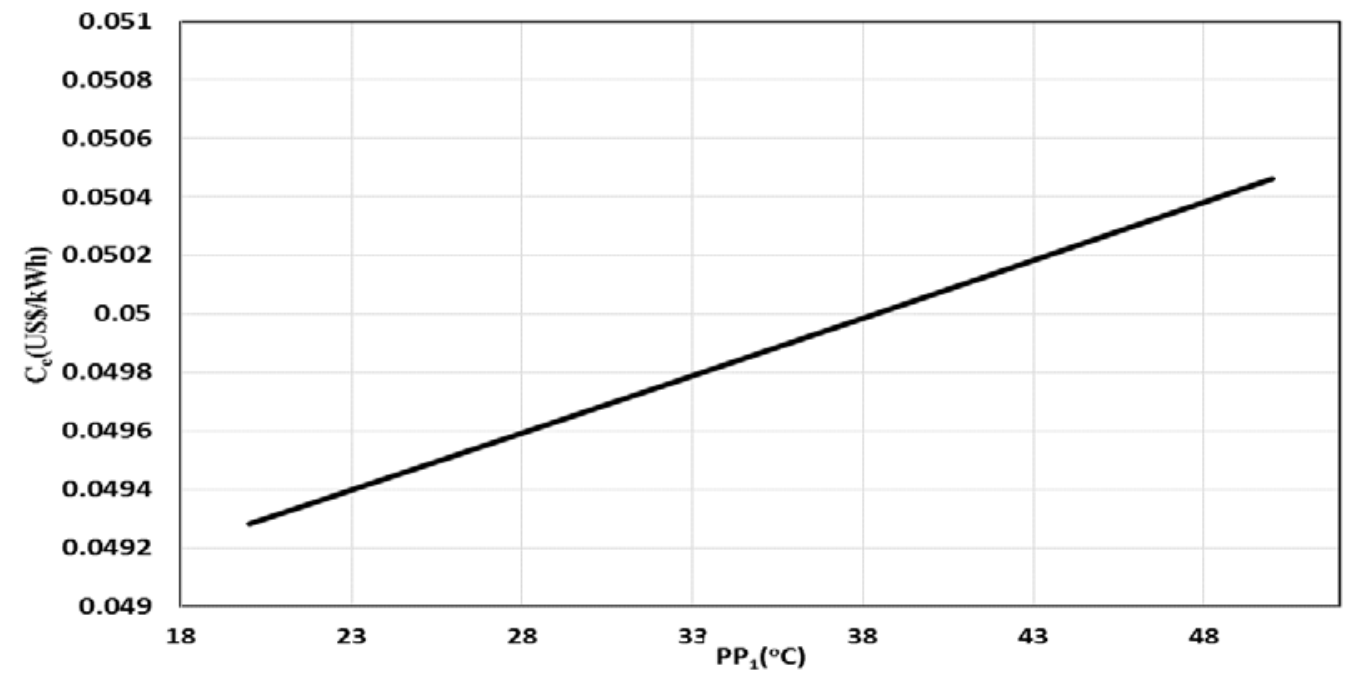

Figure 12. The cost of electricity generated by the tri-generation cycle per $\left(\mathrm{PP}_{1}\right)$

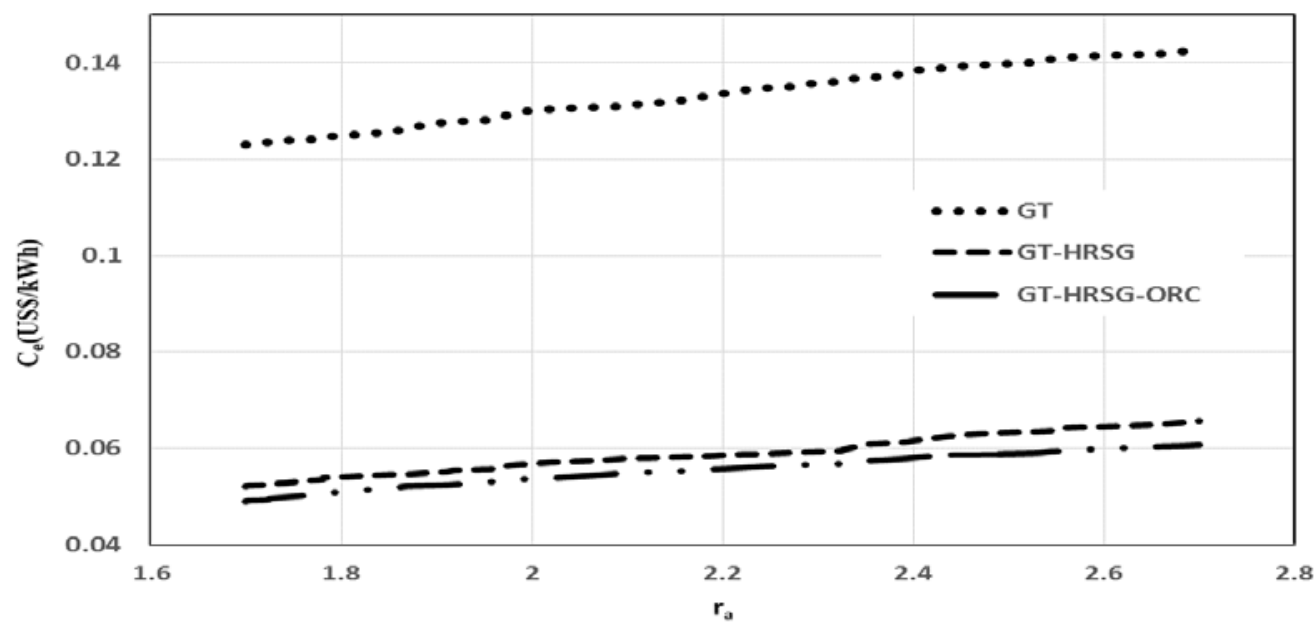

Figure 13. The cost of electricity generated by the (GT,GT+HRSG,GT+HRSG+ORC) cycles per air-to-fuel molar ratio $\left(r_{a}\right)$

Figure 14 shows the changes in costs of the electricity generated by the tri-generation cycle, per different values of gas turbine expansion ratio. It is clear from the figure that the effects of the gas turbine expansion coefficients changes on the cost of electricity generated by the tri-generation cycle are negligible. 


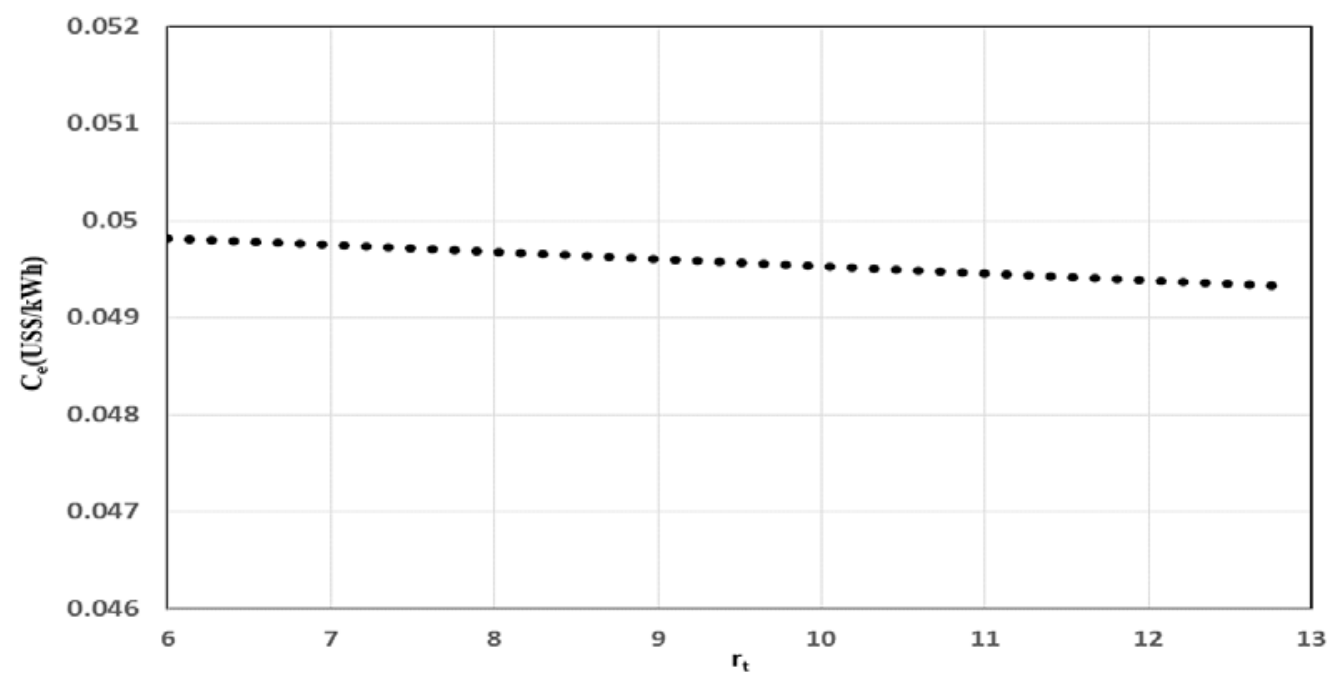

Figure 14. The cost of electricity per gas expansion ratio $\left(\mathrm{r}_{\mathrm{t}}\right)$

Figure 15 shows the efficiency of the first law of thermodynamics for gas turbine cycle (GT), gas and steam cycle (GT+HRSG), and tri-generation cycle (GT+HRSG+ORC), before and after optimization by the dualpurpose genetic algorithm. Regarding the values of the efficiency of the first law of thermodynamics before and after optimization, it can be concluded that optimization in GT, GT+HRSG, and tri-generation cycle leads to the increase in efficiency of the first law of thermodynamics by $41.5 \%, 29.9 \%$, and $29.2 \%$, respectively. Figure 16 shows the efficiency of the second law of thermodynamics for the (GT, GT+HRSG,GT+HRSG+ORC) cycles, before and after optimization. This optimization leads to increase in the second law of thermodynamics by $41.7 \%$, $30 \%$, and $29.3 \%$ for the GT cycle, GT+HRSG, and GT+HRSG+GT+HRSG+ORC, respectively. Figure 17 shows the entropy production by the GT cycle, GT+HRSG, and GT+HRSG+GT+HRSG+ORC, before and after optimization. It can be read from the values in the figure that despite the increase in the first and second laws of the thermodynamics after optimization, the entropy production is also increased for all three cycles.

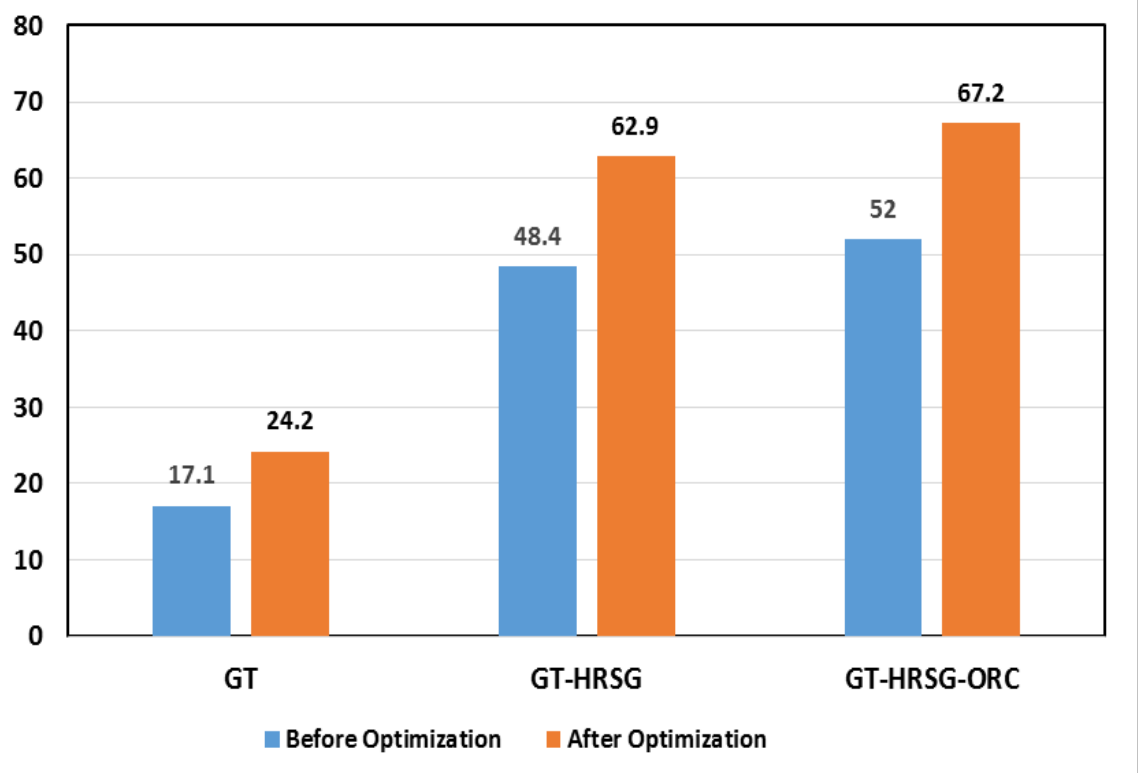

Figure 15. The efficiency of the first law of thermodynamics for (GT,GT+HRSG,GT+HRSG+ORC) before and after optimization 
Journal of Thermal Engineering, Research Article, Vol. 6, No. 2, Special Issue 11, pp. 65-91, March, 2020

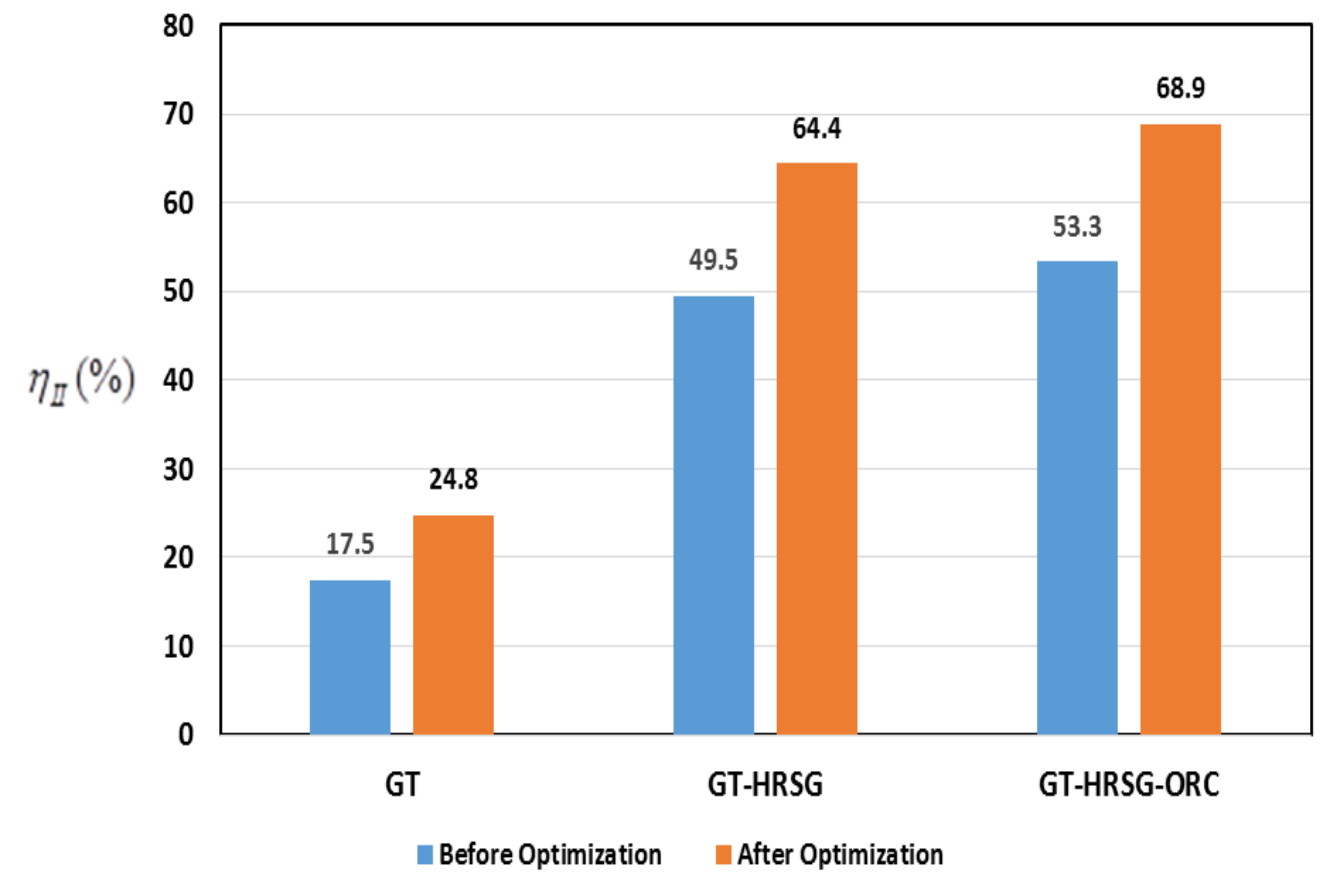

Figure 16. The efficiency of the second law of thermodynamics for (GT, GT+HRSG, GT+HRSG+ORC) before and after optimization

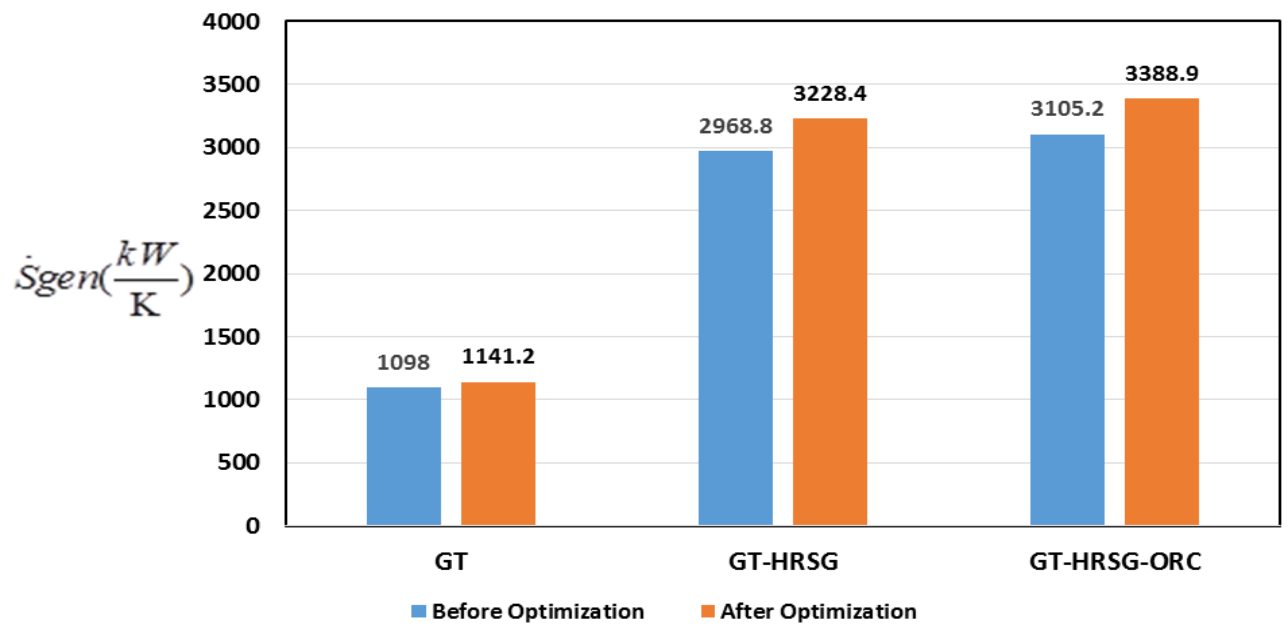

Figure 17. Entropy production by the (GT,GT+HRSG,GT+HRSG+ORC) before and after optimization

Figure 18 shows the cost of electricity generated by the GT,GT+HRSG, and GT+HRSG+ORC, pre- and afteroptimization. The figure shows that the although the energy recycling in each cycle leads to higher costs of new equipment and initial cost, the electricity cost is reduced, considering the cycles efficiency and decrease in the fuel consumption in a constant amount power generation. On the other hand, application of optimization on the cycles also leads to the decrease in power generation costs, in a way that the cost is reduced by 30,22 , and $22 \%$ respectively, for the GT, GT+HRSG, and GT+HRSG+ORC cycles, compared to pre-optimization. 


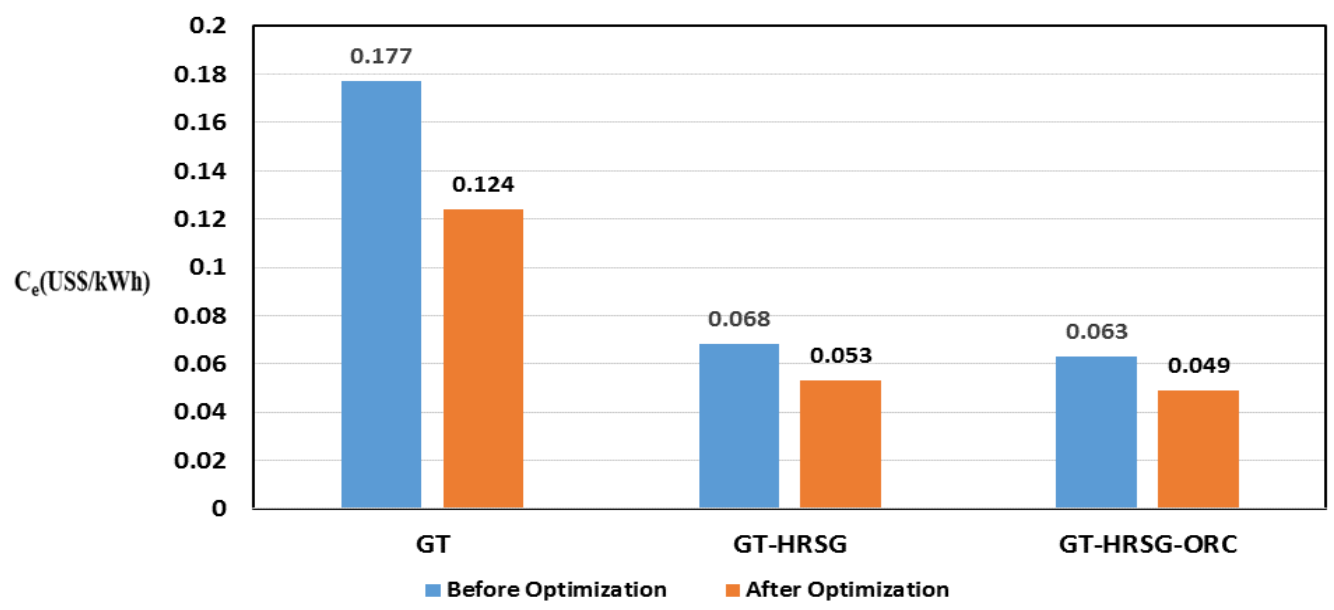

Figure 18. The cost of the electricity generated by the GT, GT+HRSG, and GT+HRSG+ORC cycles, before and after optimization

\section{CONCLUSION}

The current study dealt with the energy, exergy, and economic modeling of a tri-generation cycle. In this cycle, the energy of gas turbine outlet hot gases was used for the production of steam and power in the steam cycle. Also, the steam cycle condenser waste energy was used for the production of the organic fluid steam and power in the ORC. After the above modeling was done, the multi-purpose genetic algorithm was used for optimization. The objective functions were the cost of the electricity generated by the cycle and the efficiency of the second law of thermodynamics. The variables investigated in optimization include the air-to-fuel molar ratio, the compressor and gas cycle turbine density and expansion ratio, mass discharge of the water and coolant, the Pinch Points between the gas and steam cycles, and steam cycle and ORC, and the maximum temperatures of the steam cycle and ORC.

The results of the current study are as follows:

- The convergence of the multi-purpose genetic algorithm for tri-generation power cycle with 200 iterations was performed.

- By the increase in the air-to-fuel ratio, the efficiency of the second law of the thermodynamics is decreased. By the increase in air compressor density ratio, a similar effect can be observed.

- By the increase in air-to-fuel ratio, the efficiency of the first law of thermodynamics in the tri-generation cycle is decreased. By the increase in air compressor density ratio, a similar effect can be observed.

- By adding the steam cycle to the gas cycle for increasing the efficiency, the efficiency of the second law of thermodynamics is increased up to 2.5 times.

- $\quad$ By adding the ORC to the GT+HRSG cycle, the efficiency is increased by about $7 \%$.

- The change in gas turbine expansion coefficient has no significant effects on the efficiency of the second law of thermodynamics in tri-generation cycle, e.g., by the increase in gas turbine expansion coefficient from 6 to 13, the efficiency of the second law of thermodynamics is only increased from $68.5 \%$ to $69 \%$.

- The increase in air-to-fuel ratio and compressor density would lead to the increase in the cost of the electricity generated by the tri-generation cycle.

- The increase in Pinch Point between hot gas and super-heat steam would lead to the increase in electricity cost.

- The GT, GT+HRSG, and GT+HRSG+ORC would lead to the increase in the first law of thermodynamics by $41.5 \%, 29.9 \%$, and $29.2 \%$, and the increase in the second law of thermodynamics by $41.7 \%, 30 \%$, and $29.3 \%$, respectively. 
- The optimization of the power generation cycle from the gas cycle to the gas and steam cycle, and the trigeneration cycle would lead to the increase in entropy, in all modes.

- In general, by the optimization of the mentioned tri-generation cycle, the electricity cost is reduced from

$$
\text { 0.0632 }\left(\frac{U S \$}{k W h}\right) \text { to } 0.049\left(\frac{U S \$}{k W h}\right) \text {. }
$$

\section{NOMENCLATURE}

\begin{tabular}{|c|c|}
\hline$c_{p}$ & Constant pressure specific heat, $\mathrm{kJ} / \mathrm{kgK}$ \\
\hline$e$ & Exergy, kJ/kg \\
\hline $\mathrm{h}$ & Enthalpy, $\mathrm{kJ} / \mathrm{kg}$ \\
\hline$h_{f}^{0}$ & Formation Enthalpy, kJ/kg \\
\hline$h_{0}$ & Reference Point Enthalpy, kJ/kg \\
\hline $\mathrm{K}$ & Equilibrium Constant Equations (9) and (10) \\
\hline $\mathrm{K}$ & Ratio of Specific heat coefficient \\
\hline$L H V$ & Lower heating value, $\mathrm{kJ} / \mathrm{kg}$ \\
\hline$M$ & Molar mass, $\mathrm{kJ} / \mathrm{kmol}$ \\
\hline$\dot{m}$ & Mass flow rate, $\mathrm{kg} / \mathrm{s}$ \\
\hline $\mathrm{N}$ & Number of moles \\
\hline$R$ & Gas constant, $\mathrm{kJ} / \mathrm{kgK}$ \\
\hline $\mathrm{R}$ & Pressure ratio \\
\hline $\mathrm{R}_{\mathrm{u}}$ & Universal gas constant \\
\hline$T$ & Temperature, ${ }^{\circ} \mathrm{C}$ \\
\hline$w$ & Work per mass flow rate, $\mathrm{kJ} / \mathrm{kg}$ \\
\hline$\dot{W}$ & Power, kW \\
\hline $\mathrm{x}$ & Mass percent \\
\hline $\mathrm{y}$ & Moral percent \\
\hline \multicolumn{2}{|c|}{ Greek symbols } \\
\hline$\eta$ & Efficiency \\
\hline \multicolumn{2}{|c|}{ Subscript } \\
\hline 1 to 19 & Points are shown in figure 1. \\
\hline bc, g & Booster compressor \\
\hline CC & Combustion chamber \\
\hline ch & Chemical \\
\hline$c, g$ & Gas compressor \\
\hline Co & Condenser \\
\hline Drum & Drum \\
\hline Есо & Economizer \\
\hline $\mathrm{f}$ & Fuel \\
\hline g & Gas cycle \\
\hline HRSG & Hear recovery steam generation \\
\hline ORC & Organic Rankine cycle \\
\hline $\mathrm{P}$ & Product (equation 11.), pump \\
\hline $\mathrm{Ph}$ & Physical \\
\hline & Reactant \\
\hline
\end{tabular}




$\begin{array}{ll}\mathrm{SH} & \text { Super heater } \\ \mathrm{St} & \text { Steam, Steam turbine (equation 23) } \\ \mathrm{T}, \mathrm{g} & \text { Gas turbine } \\ \mathrm{t} & \text { Total }\end{array}$

\section{REFERENCES}

[1] Darvish K, Ehyaei M, Atabi F, Rosen M. Selection of Optimum Working Fluid for Organic Rankine Cycles by Exergy and Exergy-Economic Analyses. Sustainability. 2015;7(11):15362-83. http://dx.doi.org/10.3390/su71115362.

[2] Tchanche BF, Lambrinos G, Frangoudakis A, Papadakis G. Low-grade heat conversion into power using organic Rankine cycles - A review of various applications. Renewable and Sustainable Energy Reviews. 2011;15(8):3963-79. http://dx.doi.org/10.1016/j.rser.2011.07.024.

[3] B. S. Working fluids for ORC Plants: Add-an circuits for waste heat utilization. VGB Kraftwerke Technik. 1986;66:419-26.

[4] Yamamoto T, Furuhata T, Arai N, Mori K. Design and testing of the Organic Rankine Cycle. Energy. 2001;26(3):239-51. http://dx.doi.org/10.1016/s0360.3-00063(00)5442-

[5] Wei D, Lu X, Lu Z, Gu J. Performance analysis and optimization of organic Rankine cycle (ORC) for waste heat recovery. Energy Conversion and Management. 2007;48(4):1113-9. http://dx.doi.org/10.1016/j.enconman.2006.10.020.

[6] Mago PJ ,Chamra LM, Somayaji C. Performance analysis of different working fluids for use in organic Rankine cycles. Proceedings of the Institution of Mechanical Engineers, Part A: Journal of Power and Energy. 2007;221(3):255-63. http://dx.doi.org/10.1243/09576509jpe372.

[7] Invernizzi C, Iora P, Silva P. Bottoming micro-Rankine cycles for micro-gas turbines. Applied Thermal Engineering. 2007;27(1):100-10. http://dx.doi.org/10.1016/j.applthermaleng.2006.05.003.

[8] Qingfu Z, Hui L. MOEA/D: A Multiobjective Evolutionary Algorithm Based on Decomposition. IEEE $\begin{array}{llll}\text { Transactions on } & \text { 2007;11(6):712-31. }\end{array}$ http://dx.doi.org/10.1109/tevc.2007.892759.

[9] Roy JP, Mishra MK, Misra A. Parametric optimization and performance analysis of a waste heat recovery system using Organic Rankine Cycle. Energy. 2010;35(12):5049-62. http://dx.doi.org/10.1016/j.energy.2010.08.013.

[10] Ahmadi P DI, Rosen MA. Exergoenvironmental analysis of a trigeneration system based on micro gas turbine and organic Rankine cycles. InProceedings of the Global Conference on Global Warming, Lisbon, Portugal 2011 Jul.

[11] Wang E, Zhang H, Fan B, Wu Y. Optimized performances comparison of organic Rankine cycles for low grade waste heat recovery. Journal of Mechanical Science and Technology. 2012;26(8):2301-12. http://dx.doi.org/10.1007/s12206-012-0603-4.

[12] Pierobon L, Nguyen T-V, Larsen U, Haglind F, Elmegaard B. Multi-objective optimization of organic Rankine cycles for waste heat recovery: Application in an offshore platform. Energy .49-58:538;2013 . http://dx.doi.org/10.1016/j.energy.2013.05.039.

[13] Wang J, Yan Z, Wang M, Ma S, Dai Y. Thermodynamic analysis and optimization of an (organic Rankine cycle) ORC using low grade heat source. Energy. 2013;49:356-65. http://dx.doi.org/10/1016.j.energy.2012.11.009.

[14] Tańczuk M, Ulbrich R. Implementation of a biomass-fired co-generation plant supplied with an ORC (Organic Rankine Cycle) as a heat source for small scale heat distribution system - A comparative analysis under Polish and German conditions. Energy. 2013;62:132-41. http://dx.doi.org/10.1016/j.energy.2013.09.044. 
Journal of Thermal Engineering, Research Article, Vol. 6, No. 2, Special Issue 11, pp. 65-91, March, 2020

[15] Clemente S, Micheli D, Reini M, Taccani R. Bottoming organic Rankine cycle for a small scale gas turbine: A comparison of different solutions. Applied Energy. 20 .64-106:355;13 http://dx.doi.org/10.1016/j.apenergy.2013.02.004.

[16] Carcasci C, Winchler L. Thermodynamic Analysis of an Organic Rankine Cycle for Waste Heat Recovery from an Aeroderivative Intercooled Gas Turbine. Energy Procedia. 2016;101:862-9. http//:dx.doi.org/10.1016/j.egypro.2016.11.109.

[17] Cao Y, Dai Y. Comparative analysis on off-design performance of a gas turbine and ORC combined cycle under different operation approaches. Energy Conversion and Management. 2017;135:84-100. http://dx.doi.org/10.1016/j.enconman.2016.12.072.

[18] Khaljani M, Khoshbakhti Saray R, Bahlouli K. Comprehensive analysis of energy, exergy and exergoeconomic of cogeneration of heat and power in a combined gas turbine and organic Rankine cycle. Energy Conversion and Management. 2015;97:154-65. http://dx.doi.org/10.1016/j.enconman.2015.02.067.

[19] Carcasci C, Ferraro R, Miliotti E. Thermodynamic analysis of an organic Rankine cycle for waste heat recovery from gas turbines. Energy. 2014;65:91-100. http://dx.doi.org/10/1016.j.energy.2013.11.080.

[20] Saidi MH, Abbassi, A. and Ehyaei, M.A. Exergetic optimisation of a PEM fuel cell for domestic hot water heater. 2005Paper no. IGEC-1-022.

[21] Saidi MH, Ehyaei MA, Abbasi A. Optimization of a combined heat and power PEFC by exergy analysis. Journal of Power Sources. 2005;143(1-2):179-84. http://dx.doi.org/10.1016/j.jpowsour.2004.11.061.

[22] Mozafari A, Ahmadi A, Ehyaei MA. Optimisation of micro gas turbine by exergy, economic and environmental (3E) analysis. International Journal of Exergy. 2010;7(1):1. http://dx.doi.org/10.1504/ijex.2010.029611.

[23] Ehyaei MA, Hakimzadeh S, Enadi N, Ahmadi P. Exergy, economic and environment (3E) analysis of absorption chiller inlet air cooler used in gas turbine power plants. International Journal of Energy Research. 2011;36(4):486-98. http://dx.doi.org/10.1002/er.1814.

[24] Ashari GR, Ehyaei MA, Mozafari A, Atabi F, Hajidavalloo E, Shalbaf S. Exergy, Economic, and Environmental Analysis of a PEM Fuel Cell Power System to Meet Electrical and Thermal Energy Needs of Residential Buildings. Journal of Fuel Cell Science and Technology. 2012;9(5): http://dx.doi.org/10.1115/1.4006049.

[25] Mozafari A, Ehyaei MA. Effects of Regeneration Heat Exchanger on Entropy, Electricity Cost, and Environmental Pollution Produced by Micro Gas Turbine System. International Journal of Green Energy. 2012;9(1):51-70. http://dx.doi.org/10.1080/15435075.2011.617021.

[26] Ehyaei MA, Tahani M, Ahmadi P, Esfandiari M. Optimization of fog inlet air cooling system for combined cycle power plants using genetic algorithm. Applied Thermal Engineering. 2015;76:449-61. http://dx.doi.org/10.1016/j.applthermaleng.2014.11.032.

[27] Yazdi B, Yazdi B, Ehyaei M, Ahmadi A. Optimization of micro combined heat and power gas turbine by genetic algorithm. Thermal Science. 2015;19(1):207-18. http://dx.doi.org/10.2298/tsci121218141y.

[28] Yazdi M, Aliehyaei M, Rosen M. Exergy, Economic and Environmental Analyses of Gas Turbine Inlet Air Cooling with a Heat Pump Using a Novel System Configuration. Sustainability. 2015;7(10):14259-86. http://dx.doi.org/10.3390/su71014259.

[29] Shamoushaki M, Ghanatir F, Ehyaei MA, Ahmadi A. Exergy and exergoeconomic analysis and multiobjective optimisation of gas turbine power plant by evolutionary algorithms. Case study: Aliabad Katoul power plant. International Journal of Exergy. 2017;22(3):279. http://dx.doi.org/10.1504/ijex.2017.083160.

[30] Shamoushaki M, Ehyaei M. Exergy, economic and environmental (3E) analysis of a gas turbine power plant and optimization by MOPSO algorithm. Thermal Science. 2018;22(6 Part A):2641-51. http://dx.doi.org/10.2298/tsci161011091s.

[31] Aliehyaei MA. Optimization Of Micro Gas Turbine By Economic, Exergy And Environment Analysis Using Genetic, Bee Colony And Searching Algorithms. Journal of Thermal Engineering. 2020:117-40. http://dx.doi.org/10.18186/thermal.672054. 
[32] Abbassi A, Aliehyaei M. Exergy method of optimisation of a wavy plate indirect evaporative cooler. International Journal of Exergy. 2004;1(3):350. http://dx.doi.org/10.1504/ijex.2004.005562.

[33] Ghasemian E, Ehyaei MA. Evaluation and optimization of organic Rankine cycle (ORC) with algorithms NSGA-II, MOPSO, and MOEA for eight coolant fluids. International Journal of Energy and Environmental Engineering. 2017;9(1):39-57. http://dx.doi.org/10.1007/s40095-017-0251-7.

[34] Kazemi H, Ehyaei MA. Energy, exergy, and economic analysis of a geothermal power plant. Advances In Geo-Energy Research. 2018;2(2):190-209. http://dx.doi.org/10.26804/ager.2018.02.07.

[35] Bachmann R NH, Warner J, Kehlhofer R. . Combined-cycle gas \& steam turbine power plants. Tulsa, OK: PennWell Publishing Company. 1999 Aug..

[36] Cohen H RG, Saravanamuttoo HI. . Gas Turbine Theory, Longman.1996.

[37] www.nigc.ir.

[38] Boles M CY. An Engineering Approach. New York: McGraw-Hil l Education. 2014.

[39] Ehyaei MA, Mozafari A, Alibiglou MH. Exergy, economic \& environmental (3E) analysis of inlet fogging for gas turbine power plant. Energy. 2011: http://dx.doi.org/10.1016/j.energy.2011.10.011.

[40] von Spakovsky M FC. . The Environomic Analysis and Optimization of a Gas Turbine Cycle with Cogeneration. 1994.

[41] Silveira JL, Tuna CE. Thermoeconomic analysis method for optimization of combined heat and power systems. Part I. Progress in Energy and Combustion Science. 2003;29(6):479-85. http://dx.doi.org/10.1016/s0360-1285(03)00041-8.

[42] Lecompte S, Huisseune H, van den Broek M, De Schampheleire S, De Paepe M. Part load based thermoeconomic optimization of the Organic Rankine Cycle (ORC (applied to a combined heat and power (CHP) system. Applied Energy. 2013;111:871-81. http://dx.doi.org/10.1016/j.apenergy.2013.06.043.

[43] Scardigno D, Fanelli E, Viggiano A, Braccio G, Magi V. A genetic optimization of a hybrid organic Rankine plant for solar and low-grade energy sources. Energy. 2015;91:807-15. http://dx.doi.org/10.1016/j.energy.2015.08.066.

[44] Cao Y, Gao Y, Zheng Y, Dai Y. Optimum design and thermodynamic analysis of a gas turbine and ORC combined cycle with recuperators. Energy Conversion and Management. 2016;116:32-41. http://dx.doi.org/10.1016/j.enconman.2016.02.073.

[45] M. M. An introduction to genetic algorithms. MIT press; 1998.

[46] N. S. Review of selection methods in genetic algorithms. International Journal Of Engineering And Computer Science. 2017 Dec 8;6(12):22261-3.

[47] https://www.nist.gov/srd/refprop .

[48] JH. H. Combined Power Plants: Including Combined Cycle Gas Turbine Plants. ISBN-13. 1975:9781575241975. 